\title{
Synthesis and reception of prostaglandins in corpora lutea of domestic cat and lynx
}

\author{
Lina Zschockelt ${ }^{1}$, Olga Amelkina¹, Marta J Siemieniuch², Mariusz P Kowalewski³, \\ Martin Dehnhard ${ }^{1}$, Katarina Jewgenow ${ }^{1}$ and Beate C Braun ${ }^{1}$ \\ ${ }^{1}$ Department of Reproduction Biology, Leibniz Institute for Zoo and Wildlife Research, \\ Berlin, Germany, ${ }^{2}$ Department of Reproductive Immunology and Pathology, Institute of Animal Reproduction and \\ Food Research, Polish Academy of Sciences, Olsztyn, Poland, and ${ }^{3}$ Institute of Veterinary Anatomy, \\ Vetsuisse Faculty, University of Zurich, Zurich, Switzerland \\ Correspondence should be addressed to L Zschockelt; Email: zschockelt@izw-berlin.de
}

\begin{abstract}
Felids show different reproductive strategies related to the luteal phase. Domestic cats exhibit a seasonal polyoestrus and ovulation is followed by formation of corpora lutea $(\mathrm{CL})$. Pregnant and non-pregnant cycles are reflected by diverging plasma progesterone (P4) profiles. Eurasian and Iberian lynxes show a seasonal monooestrus, in which physiologically persistent CL (perCL) support constantly elevated plasma P4 levels. Prostaglandins (PGs) represent key regulators of reproduction, and we aimed to characterise PG synthesis in feline CL to identify their contribution to the luteal lifespan. We assessed mRNA and protein expression of PG synthases (PTGS2/

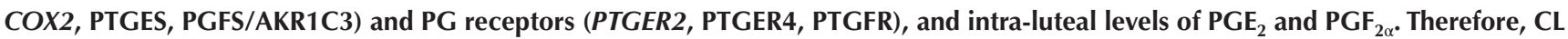
of pregnant (pre-implantation, post-implantation, regression stages) and non-pregnant (formation, development/maintenance, early regression, late regression stages) domestic cats, and prooestrous Eurasian (perCL, pre-mating) and metoestrous Iberian (perCL, freshCL, post-mating) lynxes were investigated. Expression of PTGS2/COX2, PTGES and PTGER4 was independent of the luteal stage in the investigated species. High levels of luteotrophic $\mathrm{PGE}_{2}$ in perCL might be associated with persistence of luteal function in lynxes. Signals for PGFS/AKR1C3 expression were weak in mid and late luteal stages of cats but were absent in lynxes, concomitant with low $\mathrm{PGF}_{2 \alpha}$ levels in these species. Thus, regulation of $\mathrm{CL}$ regression by luteal $\mathrm{PGF}_{2 \alpha}$ seems negligible. In contrast, expression of PTGFR was evident in nearly all investigated CL of cat and lynxes, implying that luteal regression, e.g. at the end of pregnancy, is triggered by extra-luteal PGF $_{2 \alpha}$.

Reproduction (2016) 152 111-126
\end{abstract}

\section{Introduction}

Reproductive biology of domestic cats (Felis silvestris $f$. catus) exhibits a characteristic feature: during seasonal polyoestrus, an induced or spontaneous ovulation can be followed by either a pregnant or a shortened nonpregnant luteal phase (Wildt et al. 1981, Lawler et al. 1993). Consequently, the formation of corpora lutea $(\mathrm{CL})$ and the functional luteal phases is reflected by different plasma progesterone (P4) profiles after days 10-12 post coitum (p.c.) (Paape et al. 1975, Verhage et al. 1976), coinciding with the time of blastocyst implantation (Leiser 1979). Significant differences between both profiles become visible around days 25-30 p.c., when pregnant cats have higher P4 levels (Verhage et al. 1976). During the non-pregnant luteal phase, plasma P4 already becomes basal at days 25-40 p.c. (Paape et al. 1975, Verhage et al. 1976). The ongoing loss of steroidogenic capacity (Siemieniuch et al. 2012, Zschockelt et al. 2014) and the concomitant structural luteal regression
(Dawson 1946, Amelkina et al. 2015a) proceed similarly throughout the sequential luteal stages of pregnant and non-pregnant luteal phases. However, it is assumed that the respective corpora lutea $(\mathrm{CL})$ enter the process of luteal regression at different time points, as CL of pregnant cats show early histomorphological signs of regression from days 38-39 onwards (Amelkina et al. 2015a), whereas plasma P4 levels indicate that $\mathrm{CL}$ of non-pregnant cats begin to regress on day 21 after their formation (Paape et al. 1975).

Compared with other felid species, the reproduction of lynxes is rather unique (Göritz et al. 2009, Jewgenow et al. 2014). In contrast to the polyoestrous bobcat (Lynx rufus (Parker \& Smith 1983)), the Canada (L. canadensis (Fanson et al. 2010)), Eurasian (L. Iynx (Kvam 1991)) and Iberian lynx (L. pardinus (Palomares et al. 2005)) are strictly seasonal monooestrous. The observation that central and northern European populations of both captive and free-ranging Eurasian lynxes show the same monooestrous strategy suggests a rather conserved reproductive adaptation without plasticity regarding 
this phenomenon (Painer et al. 2014b). Lynxes develop physiologically persistent CL (perCL) (Göritz et al. 2009, Fanson et al. 2010) present for at least two subsequent years (Painer et al. 2014b). Thus, on the same ovary, CL formed freshly during the breeding season (freshCL) with high steroidogenic capacity coexist with previous years' perCL (Amelkina et al. 2015b) of present but lower steroidogenic capacity (Carnaby et al. 2012, Zschockelt et al. 2015). However, functionality of these perCL is sufficient to support constantly elevated P4 plasma levels throughout the year, which is hypothesised to ensure a monooestrous cyclicity by preventing folliculogenesis and ovulation outside the breeding season (Göritz et al. 2009, Painer et al. 2014b). Despite constant luteal activity of structurally preserved $\mathrm{CL}$, lynxes enter oestrus in springtime and increasing evidence points to a temporarily reduced function of perCL before breeding and parturition (Painer et al. 2014b, Zschockelt et al. 2015). Because there are no confounding differences regarding reproduction, the closely related Eurasian lynx is commonly used as a model species to investigate the reproductive physiology of the Iberian lynx (Göritz et al. 2009, Painer et al. 2014b, Amelkina et al. 2015b, Zschockelt et al. 2015). The latter was declared critically endangered in 2002. Due to integrated conservation efforts, the species was downgraded to endangered by the International Union for Conservation of Nature in 2015. Compilation of reproductive research on domestic cats, Eurasian lynxes and, if possible, on Iberian lynxes supports the development of assisted reproduction techniques for endangered felid species.

The autocrine/paracrine role of luteal prostaglandins (PGs) in CL function is evident in many mammalian species (Olofsson \& Leung 1994, Wiltbank \& Ottobre 2003). The PGs are metabolites of arachidonic acid (AA) liberated from phospholipid cell membranes by cytosolic phospholipase $\mathrm{A}_{2}\left(\mathrm{CPLA}_{2}\right)$ (Smith \& Dewitt 1996). The conversion of free $\mathrm{AA}$ into prostaglandin $\mathrm{G}_{2} / \mathrm{H}_{2}\left(\mathrm{PGG}_{2} /\right.$ $\mathrm{PGH}_{2}$ ) is catalysed by two isoforms of prostaglandinendoperoxide synthase/cyclooxygenase (PTGS/COX) which differ in the regulation of their expression and tissue distribution (Wiltbank \& Ottobre 2003). The common precursor $\mathrm{PGH}_{2}$ is selectively converted to active PGs by specific terminal synthases like different prostaglandin $\mathrm{E}$ synthases (e.g. PTGES) for $\mathrm{PGE}_{2}$ and several prostaglandin $\mathrm{F}$ synthases (PGFS; e.g. aldo-keto reductase family 1 , member C3 (AKR1C3)) for $\mathrm{PGF}_{2 \alpha}$ (Smith \& Dewitt 1996). Inactivation of plasma $\mathrm{PGE}_{2}$ to

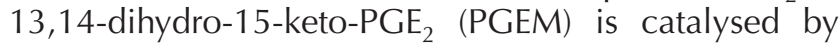
HPGD (hydroxyprostaglandin dehydrogenase 15-(NAD)) (Tai et al. 2002). Similarly, PGF $_{2 \alpha}$ is rapidly inactivated by HPGD in the lungs to its metabolite 13,14-dihydro15-keto-PGF ${ }_{2 \alpha}$ (PGFM) (Tai et al. 2002). Action of $\mathrm{PGE}_{2}$ is mediated via multiple $G$ protein-coupled membrane receptors, e.g. PTGER2 and PTGER4. After ligand binding, these subtypes mediate their effects through $G$ proteins that stimulate adenylyl cyclase. The resulting increased
cAMP level leads to activation of the PKA-signalling pathway (Marsh \& LeMaire 1974). A luteotrophic effect of $\mathrm{PGE}_{2}$ was indicated, as it was shown to stimulate P4 secretion in bovine (Kotwica et al. 2003), ovine (Weems et al. 1997) and canine (Kowalewski et al. 2013) luteal cell cultures. The receptor of PGF $_{2 \alpha}$ (PTGFR) belongs to the seven-transmembrane family of $G$ protein-coupled receptors, generating different second messengers after ligand binding (Sugimoto et al. 1994). The conserved role of $\mathrm{PGF}_{2 \alpha}$ in mediating luteal regression is generally accepted (Niswender et al. 2000, Arosh et al. 2004). Prostaglandin $F_{2 \alpha}$ decreases luteal synthesis of P4 in cows, ewes, humans and sows (Niswender et al. 1994). It affects $\mathrm{P} 4$ production by interfering with cholesterol transport into steroidogenic cells (McLean et al. 1995) or by enhancing P4 metabolism (Stocco et al. 2000). The cyclical regression of the $\mathrm{CL}$ is initiated by the secretion of $\mathrm{PGF}_{2 \alpha}$ from the uterus in many non-primate mammalian species (McCracken et al. 1999). In these species, it triggers the luteal production of $\mathrm{PGF}_{2 \alpha}$ (Tsai \& Wiltbank 1997, Arosh et al. 2004), probably crucial for complete structural regression (Diaz et al. 2002, Hayashi et al. 2003). In primates, luteal regression is mediated by $\mathrm{PGF}_{2 \alpha}$ of luteal rather than uterine origin (Nagle et al. 2005).

In plasma of Eurasian lynxes (Painer et al. 2014b) and domestic cats (Siemieniuch et al. 2014), PGFM levels increase during the last trimester of gestation until a pre-partal peak. In the pregnant domestic cat, it is assumed that PGFM plasma elevations in late pregnancy mainly reflect substantial placental PGF $_{2 \alpha}$ production (Tsutsui \& Stabenfeldt 1993, Siemieniuch et al. 2014). This, however, does not rule out an intraluteal source of $\mathrm{PGF}_{2 \alpha}$. In cats and lynxes, the prepartal PGFM elevation is accompanied by a decline in plasma P4 (Siemieniuch et al. 2012, Painer et al. 2014b), indicative of functional luteal regression; however, no complete structural regression, as suggested for the cat (Dawson 1946, Amelkina et al. 2015a), is observed in lynxes (Painer et al. 2014b). A smaller increase in plasma PGFM, concomitant with a P4 decrease, was shown in prooestrous lynxes (Painer et al. 2014b). Based on an earlier study on intra-luteal PG synthesis in lynxes (Jewgenow et al. 2012), it was proposed that an intra-luteal signal for the temporary functional luteal regression of perCL might occur before oestrus (Jewgenow et al. 2014), as a prerequisite for follicular growth and ovulation.

We assumed that the feline $\mathrm{CL}$ lifespan is regulated by the luteal capacity to synthesise and respond to PGs. Thus, the intra-luteal expression of PG synthases (PTGS2/COX2, PTGES, PGFS/AKR1C3) and PG receptors (PTGER2, PTGER4, PTGFR), and intra-luteal levels of $\mathrm{PGE}_{2}$ and $\mathrm{PGF}_{2 \alpha}$, were assessed. We aimed to deduce potential implications of intra-luteal PGs (i) to initiate onset of luteal regression at the end of the pregnant and non-pregnant luteal phases in cats, (ii) to 
maintain CL persistence in lynxes and (iii) to transiently reduce functionality of perCL before oestrus. Knowledge on the species-specific ovarian physiology and the lifespan of $C L$ could be implemented in conservation management plans to improve the reproductive potential of endangered Iberian lynxes by assisted reproduction techniques.

\section{Materials and methods}

\section{Animals}

The methods applied, and the study design, were approved by the Internal Committee for Ethics and Animal Welfare of the Leibniz Institute for Zoo and Wildlife Research in Berlin, Germany (Permit numbers: 2010-10-01 and 2011-01-01). The tissue from domestic cats was obtained from local animal shelters and clinics after ovariohysterectomy for the purpose of permanent contraception. This was not related to the study. The tissue from late pregnancy castration of domestic cats was obtained from the Institute of Animal Reproduction and Food Research, and all procedures were approved by the Local Animal Care and Use Committee in Olsztyn, Poland (Permit numbers: No. 41/2007/N and 61/2010/DTN). The Norwegian Experimental Animal Ethics Committee approved the collection of the ovarian tissue from Eurasian lynxes hunted legally for management purposes (Permit number: 2010/161554). Samples of Eurasian lynxes from Sweden became mainly available in the context of a legal hunting quota to maintain appropriate population levels (Swedish Government 2009, proposition 2008/09:2010, a new large carnivore management plan). The tissue from Iberian lynxes was collected after ovariohysterectomy for permanent contraception at breeding centres (Centro de Cría de Lince Ibérico El Acebuche, Parque Nacional de Doñana, Huelva, Spain and Centro Nacional de Reprodução do Lince Ibérico, Silves, Portugal), which was not related to the study.

\section{Tissue collection}

Ovaries and uteri of domestic cats were collected over a period of three breeding seasons (2012-2014; Table 1). Transportation was at $4^{\circ} \mathrm{C}$ in supplemented MEM-HEPES medium, and the $\mathrm{CL}$ were isolated immediately after arrival at the laboratory $(2-4 \mathrm{~h}$ after surgery). The day of pregnancy was determined by the stage of pre-implantation embryos flushed from the oviduct (<day 5 p.c. (Knospe 2002); a day 10 embryo was flushed from the uterine horn), the diameter of the gestation chamber ( $<$ day 20 p.c. (Zambelli \& Prati 2006)) or the foetal crown-rump length (>day 20 p.c. (Schnorr \& Kressin 2006)). Accordingly, $\mathrm{CL}$ of pregnant cats were assigned to three stages: the preimplantation stage (PRI) included samples from days 2-10 p.c.; the post-implantation stage (POI) included samples from days 14-36 p.c.; the regression stage (R) was represented by samples from days 38-48 p.c. Because the time of ovulation was unknown and embryos or foetuses were absent in the oviducts or uteri, the $\mathrm{CL}$ stages of the non-pregnant luteal phase were determined histomorphologically according to Amelkina and coworkers (2015a), including parameters of cell shape, type and degree of vacuolation, nucleus condition and the ratio of non-steroidogenic to luteal cells. The $\mathrm{CL}$ were assigned to four stages: formation (F; highly neovascularised CL contained

Table 1 Animals and tissue collection.

\begin{tabular}{|c|c|c|c|c|c|c|c|}
\hline Species & $\begin{array}{l}\text { Collaborative } \\
\text { institution }\end{array}$ & Living condition & Collection period & Tissue preservation* & $\begin{array}{c}\text { Number of } \\
\text { animal }\end{array}$ & $\begin{array}{c}\text { Number of } \\
\mathrm{CL}^{* *}\end{array}$ & $\begin{array}{l}\text { CL per } \\
\text { animal }\end{array}$ \\
\hline \multirow[t]{2}{*}{ F. catus } & $\begin{array}{l}\text { Germany, Poland } \\
\text { (IZW, ZIPR); } \\
\text { animal shelters } \\
\text { and clinics }\end{array}$ & Feral, domestic & $\begin{array}{l}3 \text { breeding } \\
\text { seasons } \\
(2012-2014)\end{array}$ & $\begin{array}{l}\text { Ovaries: } 4^{\circ} \mathrm{C} \text {, supplemented } \\
\text { MEM-HEPES medium }\end{array}$ & 45 & 45 & 1 \\
\hline & & & & $\begin{array}{l}C L \text { : isolated } 2-4 \mathrm{~h} \text { after surgery - } \\
\text { Bouin's solution; liquid } \\
\text { nitrogen, stored at }-80^{\circ} \mathrm{C}\end{array}$ & & & \\
\hline L. lynx & $\begin{array}{r}\text { Norway (SNO); } \\
\text { legal hunting }\end{array}$ & Free-ranging & February 2011 & $\begin{array}{l}C L \text { : isolated immediately after } \\
\text { dissection - Bouin's solution; } \\
\text { RNAlater RNA Stabilization } \\
\text { Reagent and liquid nitrogen, } \\
\text { stored at }-80^{\circ} \mathrm{C}\end{array}$ & 5 & 18 & 2 or 4 \\
\hline \multirow[t]{2}{*}{ L. Iynx } & $\begin{array}{l}\text { Sweden (SVA); } \\
\text { carcass } \\
\text { harvesting }\end{array}$ & Free-ranging & 2003-2010 & $\begin{array}{l}\text { Ovaries: }-20^{\circ} \mathrm{C} \text {, tissue bank } \\
\text { facility }\end{array}$ & 30 & 144 & 1 to 14 \\
\hline & & & & $\begin{array}{l}C L \text { : isolated after thawing - } \\
\text { Bouin's solution; directly } \\
\text { processed for hormone extraction }\end{array}$ & & & \\
\hline L. pardinus & $\begin{array}{l}\text { Portugal, } \\
\text { Spain (ILCBP); } \\
\text { breeding centres }\end{array}$ & Captive & February 2013 & $\begin{array}{l}C L \text { : isolated immediately after } \\
\text { surgery - Bouin's solution; } \\
\text { RNAlater RNA Stabilization } \\
\text { Reagent and liquid nitrogen, } \\
\text { stored at }-80^{\circ} \mathrm{C}\end{array}$ & 2 & 22 & 11 \\
\hline
\end{tabular}

*for transport to the laboratory and until processing; **number of analysed CL: due to limitation of luteal tissue histological, molecular and hormonal analyses were not always performed on the same CL resulting in alternate sample sizes for different assays; CL, corpus luteum; ILCBP, Iberian Lynx Captive Breeding Programme; IZW, Leibniz Institute for Zoo and Wildlife Research; SNO, Statens Naturoppsyn; SVA, Statens Veterinärmedicinska Anstalt; ZIPR, Institute of Animal Reproduction and Food Research. 
a mixture of predominantly small transforming follicular cells with different degrees of luteinisation), development/ maintenance (D/M; polyhedral luteal cells were increased in size and exhibited accumulation of numerous lipid droplets), early regression (ER; $C L$ revealed first signs of luteal regression, large vacuoles were coarsely organised all over the cells and the ratio of non-steroidogenic to luteal cells was increased) and late regression (LR; CL showed extreme cell modifications with small, deformed luteal cells containing small condensed nuclei, vacuoles were without reaction to lipid staining). Corpora albicantia (CA; luteal cells with condensed nuclei were highly modified and prominently smaller luteal cells became outnumbered by non-steroidogenic cells) considered the last stage of the CL lifespan, were not assigned to either pregnancy or the non-pregnant luteal phase. The number of $\mathrm{CL}$ per analysed luteal stage was depicted as $\left(n_{\mathrm{CL}}\right)$. To achieve independent data for gene expression and hormone analyses, each animal was represented by one randomly selected CL.

Ovarian tissue from five Eurasian lynxes (EL1-EL5; Table 1) found to be in prooestrus, respectively, pre-mating (for detailed description of the reproductive stages, see Painer and coworkers $(2014 b)$ ) was collected freshly post-mortem in February 2011 in Norway (Statens Naturoppsyn, SNO; Trondheim). Within the Iberian Lynx Captive Breeding Programme (ILCBP (Vargas et al. 2008)), two metoestrous Iberian lynxes (IL1, IL2; day 7 p.c., post-mating) were ovariohysterectomised in February 2013 (Table 1). The CL were isolated immediately after surgery. The collected CL of Eurasian and Iberian lynxes were histomorphologically staged using established domestic cat CL parameters (Amelkina et al. 2015a,b). Isolated perCL of Eurasian lynxes were in the early regression stage, whereas the ovaries of both Iberian lynxes revealed coexistence of perCL (maintenance stage) and freshCL (formation stage). The number of $\mathrm{CL}$ per analysed luteal stage was depicted as $\left(n_{\mathrm{CL}}\right)$ for gene expression analysis. To achieve independent data, each luteal stage was represented by CL of individual animals. For hormone analysis, the number of $C L$ per analysed luteal stage was depicted as ( $n_{\text {animal }} / n_{\mathrm{CL}}$; data dependent).

Each feline CL was dissected and pieces were either fixed in Bouin's solution (for histology and protein analyses), placed in RNAlater RNA Stabilization Reagent (for RNA isolation, Eurasian and Iberian lynx; Qiagen $\mathrm{GmbH}$ ) or liquid nitrogen (for RNA isolation; domestic cat). For hormone analyses, the tissue was transferred to liquid nitrogen. These various solutions were applied to adequately preserve the tissues collected under different conditions.

Additional ovaries and uteri from Eurasian lynxes were obtained from the Statens Veterinärmedicinska Anstalt (SVA; Uppsala, Sweden), where all lynx specimens harvested after, e.g. legal hunting or killed by traffic accidents are delivered (Table 1). At the SVA, the tissue was frozen soon after the animal was necropsied; samples were collected between 2003 and 2010 and kept in frozen storage $\left(-20^{\circ} \mathrm{C}\right)$ in a tissue-bank facility. In the laboratory, ovaries and uteri were defrosted and dissected. A section of CL tissue was fixed in Bouin's solution or directly processed for hormone extraction. These $C L$ were grouped by month and assigned to different reproductive stages according to Painer and coworkers (2014b): prooestrus (Jan, Feb), oestrus (Mar), metoestrus (Apr) and prolonged dioestrus (Sep-Dec). The CL obtained from two pregnant animals in April were further separated into perCL (markedly smaller in size, dark red in colouration) and freshCL (bigger in size, pale colour) according to size and appearance. These pregnancies were confirmed by the presence of two foetuses in each animal. For hormone analysis, the number of $\mathrm{CL}$ per analysed month was depicted as $\left(n_{\text {animal }} / n_{\mathrm{CL}}\right)$, representing $\mathrm{CL}$ obtained from multiple animals (data dependent).

\section{Sequence analysis}

Information on cat-specific sequences for PTGS2/COX2 (GenBank accession EF036473 (Siemieniuch et al. 2011)), PTGES (GenBank accession GU059259 (Siemieniuch et al. 2013)), PGFS/AKR1C3 (GenBank accession HM490147 (Siemieniuch et al. 2013)) and the validated reference gene cyclophilin A (CYC, GenBank accession AY029366 (Siemieniuch et al. 2012, Jursza et al. 2014)) was published previously. Based on templates of feline luteal tissue, sequence information for PTGER2 (GenBank accession EF177829), PTGER4 (GenBank accession EF177830) and PTGFR (GenBank accession AF272340) was obtained for this study (Table 2).

Total RNA isolation from reproductive tissues of Eurasian and Iberian lynxes (innuSPEED Tissue RNA/innuPREP DNase I Digest Kit; Analytik Jena AG, Jena, Germany) and reverse transcription to cDNA (RevertAid First Strand cDNA Synthesis Kit; Life Technologies $\mathrm{GmbH}$ ) was performed as described previously (Zschockelt et al. 2014, 2015). Lynx-specific sequences of the studied genes were not annotated in GenBank before the study. Therefore, primers for the polymerase chain reaction (PCR) were based on gene sequences of the domestic cat or on consensus sequences derived from multiple species sequence alignments (CLC Sequence Viewer 6.7; CLC bio, Aarhus, Denmark). The primers were purchased from BioTeZ Berlin Buch GmbH (Berlin, Germany; Table 2). Partial cDNA sequences were amplified from luteal, ovarian or placental tissue using the Expand High Fidelity PLUS PCR System (Roche Diagnostics $\mathrm{GmbH}$ ), as defined previously (Braun et al. 2012). The PCR reactions were conducted at $94^{\circ} \mathrm{C}$ for $2 \mathrm{~min}$ followed by 35 cycles of denaturation $\left(94^{\circ} \mathrm{C}\right)$ for $30 \mathrm{~s}$ (PTGES, PGFS/ AKR1C3) or $45 \mathrm{~s}$ (PTGS2/COX2, PTGER2, PTGFR), annealing for $30 \mathrm{~s}$ (PTCES, PGFS/AKR1C3) or $45 \mathrm{~s}$ (PTGS2/COX2, PTGER2, PTGFR; for temperatures see Table 2), elongation $\left(72^{\circ} \mathrm{C}\right.$ ) for $30 \mathrm{~s}$ (PTGES) or $40 \mathrm{~s}$ (PGFS/AKR 1C3) or $60 \mathrm{~s}$ (PTGS2/ COX2, PTGER2, PTGFR) and a final elongation at $72^{\circ} \mathrm{C}$ for $7 \mathrm{~min}$. For amplification of PTGER4 cDNA, the TrueStart Taq DNA Polymerase Kit (Life Technologies $\mathrm{GmbH}$ ) was used with $95^{\circ} \mathrm{C} / 2 \mathrm{~min} ; 35$ cycles of $95^{\circ} \mathrm{C} / 45 \mathrm{~s}, 51^{\circ} \mathrm{C} / 45 \mathrm{~s}, 72^{\circ} \mathrm{C} / 60 \mathrm{~s}$, and $72^{\circ} \mathrm{C} / 7 \mathrm{~min}$. Purified PCR products of all genes were ligated into the $\mathrm{pCR}^{\mathrm{TM}} 4$-TOPO vector and transformed into One Shot TOP10 cells (both from Life Technologies $\mathrm{GmbH}$ ). Sequencing of clones or purified PCR products was performed by the Services in Molecular Biology GmbH (Dr M Meixner, Brandenburg, Germany). Lynx-specific sequence information and validation of the reference genes $\beta$-actin (BACT, GenBank accession KM458620), glyceraldehyde 3-phosphate dehydrogenase (GAPDH, GenBank accession KM458621), ribosomal protein S7 (RPS7, GenBank accession JX993349) and TATA box-binding protein (TBP, GenBank accession JX993351; all Lynx pardinus) were presented previously (Zschockelt et al. 2015). 
Table 2 Sequence analysis.

\begin{tabular}{|c|c|c|c|c|c|}
\hline GenBank accession & Species & Primer sequence $5^{\prime}-3^{\prime}$ & $\mathbf{T}_{\mathrm{A}}\left({ }^{\circ} \mathrm{C}\right)$ & Product size (bp) & Use \\
\hline \multicolumn{6}{|l|}{ Genes of interest } \\
\hline PTGS2/COX2* & L. pardinus & $\begin{array}{l}\text { PTGS2/COX2 Fw-1: CAC TAC AWA CTT ACC CAC TTC } \\
\text { PTGS2/COX2 Rv-1: AGG GGA TGC CAG TGG TAG A }\end{array}$ & 55 & 784 & $\mathrm{a}$ \\
\hline KT119408 & & $\begin{array}{l}\text { PTGS2/COX2 qFw-1: CAG GAG GTC TTT GGT CTG G } \\
\text { PTGS2/COX2 qRv-1: CCT ATC AGT ATT AGC CTG CT }\end{array}$ & 55 & 149 & $\mathrm{~b}$ \\
\hline PTGS2/COX2 & F. catus & $\begin{array}{l}\text { PTGS2/COX2 Fw-2: TCG ACC AGA GCA GAC AGA TG } \\
\text { PTGS2/COX2 Rv-2: CTG AAT CGA GGC AGT GTT GA }\end{array}$ & 64 & 341 & $\mathrm{a}$ \\
\hline EF036473 & & $\begin{array}{l}\text { PTCS2/COX2 qFw-2: AAC AGG AGC ATC CAG AAT GG } \\
\text { PTGS2/COX2 qRv-2: GCA GCT CTG GGT CAA ACT TC }\end{array}$ & 60 & 147 & $\mathrm{~b}$ \\
\hline PTGES* & L. Iynx & $\begin{array}{l}\text { PTGES Fw-1: GCT GGT CAT CAA GAT GTA CG } \\
\text { PTGES Rv-1: GCT TCC CAG ACG ATC TGS A }\end{array}$ & 55 & 339 & a \\
\hline KM982690 & & $\begin{array}{l}\text { PTGES qFw-1: TCG CTG CCT CAG AGC CCA } \\
\text { PTGES qRv-1: TAG GCC ACG GTG TGC ACC }\end{array}$ & 66 & 153 & $\mathrm{~b}$ \\
\hline PTGES & F. catus & $\begin{array}{l}\text { PTCES Fw-2: ACC ATC TAC CCC TTC CTG } \\
\text { PTCES Rv-2: CAG CTT CCC AGA CGA TCT }\end{array}$ & 57 & 214 & $\mathrm{a}$ \\
\hline GU059259 & & $\begin{array}{l}\text { PTGES qFw-2: GGC CTC GTT TAC TCC TTC CT } \\
\text { PTCES qRv-2: CCG AAG CTT GCC CAG ATA G }\end{array}$ & 60 & 111 & $\mathrm{~b}$ \\
\hline PTGER2* & L. Iynx & $\begin{array}{l}\text { PTGER2 Fw-1: GTT CCA CGT GCT GGT GAC A } \\
\text { PTGER2 Rv-1: GAT GGC AAA GAC CCA AGG G }\end{array}$ & 55 & 716 & a \\
\hline KM982691 & & $\begin{array}{l}\text { PTGER2 qFw-1: GAG GGG AAA GGC TGT CCA } \\
\text { PTGER2 qRv-1: GCA AAA ATT GTG AAA GGC AAG }\end{array}$ & 56.5 & 103 & $\mathrm{~b}$ \\
\hline PTCER2* & F. catus & $\begin{array}{l}\text { PTGER2 FW-2: AAC TAC GGC CAG TAC GTC CA } \\
\text { PTGER2 Rv-2: CGG GAA GAC GTT TCA TTC AT }\end{array}$ & 60 & 356 & $\mathrm{a}$ \\
\hline EF177829 & & $\begin{array}{l}\text { PTGER2 qFw-2: CTT CTA CCA GCG TCG TGT CA } \\
\text { PTCER2 qRv-2: ACT GGC CGT AGT TCA GCA AC }\end{array}$ & 60 & 107 & $b$ \\
\hline PTGER4* & L. Iynx & $\begin{array}{l}\text { PTGER4 FW-1: AGC GCT ACC TGG CCA TCA A } \\
\text { PTGER4 Rv-1: GAT AAG TTC AGT GTT TCA YTG G }\end{array}$ & 51 & 830 & $\mathrm{a}$ \\
\hline КР027417 & & $\begin{array}{l}\text { PTGER4 qFw-1: GGG TGC CGA GAT CCA GAT } \\
\text { PTGER4 qRv-1: TGG TTG ATG AAC ACC CGT AC }\end{array}$ & 56.5 & 97 & $\mathrm{~b}$ \\
\hline PTCER4* & F. catus & $\begin{array}{l}\text { PTGER4 Fw-2: TTG CTG TCT ATG CGT CCA AC } \\
\text { PTGER4 Rv-2: GGA GGT GGC GAT GAG TAA GA }\end{array}$ & 61 & 426 & $\mathrm{a}$ \\
\hline EF177830 & & $\begin{array}{l}\text { PTGER4 qFw-2: TTG CTG TCT ATG CGT CCA AC } \\
\text { PTCER4 qRv-2: TCC AGT CGA TGA AAC ACC AG }\end{array}$ & 60 & 102 & $\mathrm{~b}$ \\
\hline PGFS/AKR1C $3^{*}$ & L. Iynx & $\begin{array}{l}\text { PGFS/AKR1C3 Fw-1: GAT GGC ACT GTG AAG AGA GA } \\
\text { PGFS/AKR1C3 Rv-1: CAT TCC TTC CCT GAG TTG GA }\end{array}$ & 55 & 215 & a \\
\hline KM982692 & & $\begin{array}{l}\text { PGFS/AKR1C3 qFw-1: AGC CCG GCC TCA AGT ACA A } \\
\text { PGFS/AKR1C3 qRv-1: CAT TCC TTC CCT GAG TTG GA }\end{array}$ & 61.5 & 145 & $b$ \\
\hline PGFS/AKR1C3 & F. catus & $\begin{array}{l}\text { PGFS/AKR1C3 Fw-2: CCATGGAGAAGTGCAAGGATT } \\
\text { PGFS/AKR1C3 Rv-2: ACC TGG AAG TTC TCC CGA AT }\end{array}$ & 61 & 400 & $\mathrm{a}$ \\
\hline HM490147 & & $\begin{array}{l}\text { PGFS/AKR1C3 qFw-2: TCA ACC AGA GCA AAC TGC TG } \\
\text { PGFS/AKR1C3 qRv-2: CAT TCC TTC CCT GAG TTG GA }\end{array}$ & 60 & 91 & b \\
\hline PTGFR* & L. Iynx & $\begin{array}{l}\text { PTGFR FW-1: CTT CAT GAC AGT GGG AAT CTT } \\
\text { PTGFR Rv-1: GCT GAT GAY ATG CAC TCC AC }\end{array}$ & 55 & 684 & a \\
\hline KM982687 & & $\begin{array}{l}\text { PTGFR qFw-1: GCT GGA GTC CAT TTC TGG TG } \\
\text { PTGFR qRv-1: CCA CGT TGC CAT TCG AAG }\end{array}$ & 61 & 104 & $b$ \\
\hline PTCFR* & F. catus & $\begin{array}{l}\text { PTGFR FW-2: CTC TGG TCT GTG CCC ACT TT } \\
\text { PTGFR Rv-2: TGA GAC CTG CCT TGT CTG TG }\end{array}$ & 62 & 378 & $\mathrm{a}$ \\
\hline AF272340 & & $\begin{array}{l}\text { PTGFR qFw-2: AGA CTT CTT TGG CCA CCT CA } \\
\text { PTGFR qRv-2: GTG GGC ACA GAC CAG AGA AT }\end{array}$ & 60 & 104 & $\mathrm{~b}$ \\
\hline \multicolumn{6}{|l|}{ Reference genes } \\
\hline$B A C T$ & L. pardinus & $\begin{array}{l}\text { BACT Fw-1: CAT CCT GAC CCT CAA GTA C } \\
\text { BACT Rv-1: TCA TGA TGG AGT TGA AGG }\end{array}$ & 51 & 625 & a \\
\hline KM458620 & & $\begin{array}{l}\text { BACT qFw-1: GAG CAG GAG ATG GCC ACG } \\
\text { BACT qRv-1: CTC GTG GAT GCC ACA GGA }\end{array}$ & 62 & 159 & $\mathrm{~b}$ \\
\hline CYC & F. catus & $\begin{array}{l}\text { CYC Fw-1: CCT TCT GTA GCT CGG GTG AG } \\
\text { CYC Rv-1: CTT GGA GGG GAG GTA AGG AG }\end{array}$ & 56 & 118 & $\mathrm{a}$ \\
\hline AY029366 & & $\begin{array}{l}\text { CYC qFw-1: CCT TCT GTA GCT CGG GTG AG } \\
\text { CYC qRv-1: CTT GGA GGG GAG GTA AGG AG }\end{array}$ & 60 & 118 & $b$ \\
\hline GAPDH & L. pardinus & $\begin{array}{l}\text { GAPDH Fw-1: CTG GTC ACC AGG GCT GCT } \\
\text { GAPDH Rv-1: CCA TGA GGT CCA CCA CCC }\end{array}$ & 53 & 640 & $\mathrm{a}$ \\
\hline KM458621 & & $\begin{array}{l}\text { GAPDH qFw-1: AAG GGT GGG GCC AAG AGG } \\
\text { GAPDH qRv-1: AGA GGG GCC AGG CAG TTG }\end{array}$ & 63.5 & 143 & $\mathrm{~b}$ \\
\hline RPS7 & L. pardinus & $\begin{array}{l}\text { RPS7 Fw-1: GCC ATG TTC AGT TCG AGC G } \\
\text { RPS7 Rv-1: GTC TAC AAC TGA AAC TCT GGG }\end{array}$ & 55 & 550 & $\mathrm{a}$ \\
\hline JX993349 & & $\begin{array}{l}\text { RPS7 qFW-1: CCT GGA GGA CTT GGT TTT CC } \\
\text { RPS7 qRv-1: CCT TGC CCG TGA GCT TCT }\end{array}$ & 61 & 164 & b \\
\hline TBP & L. pardinus & $\begin{array}{l}\text { TBP Fw-1: ATG GAT CAG AAC AAC AGC CTG } \\
\text { TBP Rv-1: GCA GGA GTA CGT TAA CAG CC }\end{array}$ & $56-51$ & 970 & a \\
\hline JX993351 & & $\begin{array}{l}\text { TBP qFw-1: AGA GAG CCC CGA ACC ACT G } \\
\text { TBP qRv-1: TTC ACA TCA CAG CTC CCC AC }\end{array}$ & 62.5 & 182 & $\mathrm{~b}$ \\
\hline
\end{tabular}

*gene sequence information analysed in this study; a, used for sequence analyses; b, used for expression studies; bp, base pair; Fw, forward; $q$, quantitative PCR; Rv, reverse; $T_{A}$, annealing temperature. 


\section{Gene expression studies by quantitative PCR (qPCR)}

Quantification of $q P C R$ results using the real-time PCR Miner method: pregnant and non-pregnant luteal phases of domestic cat

Homogenisation of domestic cat luteal tissue (up to $22 \mathrm{mg}$ ), total RNA extraction and reverse transcription to cDNA was done as described previously (Zschockelt et al. 2014). No-reverse-transcription controls were included to test for genomic DNA contamination. Quality and integrity of RNA were assessed via microfluidic analysis of the respective RNA intactness using the Agilent 2100 Bioanalyzer and the Agilent RNA 6000 Nano or Pico Kits (Agilent Technologies Deutschland $\mathrm{GmbH}$ ); RNA integrity number (RIN) values were above 7.0 (up to 9.7 and 10), representing a rather intact state of total RNA. Additionally, RNA concentration and purity were validated by the NanoDrop ND-1000 (Peqlab Biotechnologie $\mathrm{GmbH}$, Erlangen, Germany). The primers were either chosen based on previous studies (PTGS2/COX2 (Siemieniuch et al. 2011), PTCES (Siemieniuch et al. 2013), PGFS/AKR1C3 (Siemieniuch et al. 2013)) or designed with the free online primer design tool Primer3 (http://simgene.com; PTCER2, PTGER4, PTGFR). All primers were purchased from BioTez Berlin Buch $\mathrm{GmbH}$ (Table 2). The relative mRNA expression of target genes was determined by qPCR with focus on the overall profile course rather than the amount of mRNA copies. This strategy eliminated the necessity of cloning external recombinant plasmid DNA for calibration. The qPCR reactions were carried out in an automated fluorometer ABI PRISM 7300 Sequence Detection System (Applied Biosystems) using the SYBR Green PCR Master Mix (Applied Biosystems). The total qPCR reaction volume was $10 \mu \mathrm{L}$ containing $3 \mu \mathrm{L}$ CDNA (corresponding to $10 \mathrm{ng}$ total RNA for genes of interest and the reference gene), $1 \mu \mathrm{L}$ each of forward and reverse primers $(500 \mathrm{nM})$ and $5 \mu \mathrm{L}$ SYBR Green PCR Master Mix $+0.1 \mu \mathrm{L}$ CRX. The qPCR conditions were as follows: initial denaturation $\left(10 \mathrm{~min}\right.$ at $\left.95^{\circ} \mathrm{C}\right)$, followed by 40 cycles of denaturation $(15 \mathrm{~s}$ at $95^{\circ} \mathrm{C}$ ) and annealing/elongation $\left(60 \mathrm{~s}\right.$ at $\left.60^{\circ} \mathrm{C}\right)$. After each qPCR reaction, melting curves were obtained by stepwise increases in temperature from 60 to $95^{\circ} \mathrm{C}$ to ensure single product amplification. Cyclophilin A was previously validated and selected among several different genes as a reference gene (Siemieniuch et al. 2012, Jursza et al. 2014). Quantification of $\mathrm{qPCR}$ results was performed by normalising the signals of target genes with the CYC signal using the real-time PCR Miner method, whereby calculation of reaction efficiency and the fractional cycle number at threshold $(\mathrm{CT})$ were based on kinetics of individual qPCR reactions (Zhao \& Fernald 2005).

\section{Quantification of $q P C R$ results using a calibration curve: prooestrus and metoestrus of Eurasian and Iberian lynx}

Lynx luteal tissue (14-26 mg) was homogenised, total RNA was extracted and reverse transcribed to CDNA as described before (Zschockelt et al. 2014, 2015). No-reverse-transcription controls were included and RNA concentration and purity were determined; RIN values were above 6.1 (up to 7 and 8.6), indicating that intactness of total RNA was only slightly lowered by moderate partial degradation. Intron-spanning primers were designed according to sequences identified in the present study (Table 2). Because cloned cDNA of Iynxspecific genes needed to be generated for sequence analysis (Sect. "sequence analysis"), standard dilutions for calibration of qPCR results were derived from the respective external recombinant plasmid DNA. This alternative strategy allowed for the determination of the relative amount of mRNA copies. For qPCR, diluted cDNA (corresponding to 2 or 10 ng total RNA for genes of interest; $4 \mathrm{ng}$ for reference genes) was analysed with the CFX96 Real-Time PCR Detection System using the SsoFast EvaGreen Supermix (both from Bio-Rad Laboratories $\mathrm{GmbH}$ ). Conditions for $\mathrm{qPCR}$ were: $98^{\circ} \mathrm{C}$ for $2 \mathrm{~min}$ and 40 cycles of denaturation at $98^{\circ} \mathrm{C}$ for $8 \mathrm{~s}$ and annealing/elongation for $8 \mathrm{~s}$ at different temperatures (Table 2). The qPCR products were quantified with the CFX Manager Software 1.6 (Bio-Rad Laboratories $\mathrm{GmbH}$ ). Fragments of BACT, GAPDH, RPS7 and $T B P$ were amplified for normalisation as described previously (Zschockelt et al. 2015). A multiple normalisation factor based on the reference gene expression was calculated for individual CL referring to Vandesompele and coworkers (2002).

\section{Protein expression studies by immunohistochemistry}

For validation of gene expression studies, immunohistochemical analysis was performed on $3 \mu \mathrm{m}$ sections of Bouin-fixed and paraffin-embedded $\mathrm{CL}$ mounted on microscope slides (Superfrost Plus; Thermo Fisher Scientific). The immunohistochemical procedure of the immunoperoxidase method for PTGES, PTGER4 and PGFS/AKR1C3 was described previously (Gram et al. 2013, 2014). For PTGFR, a protocol referring to a previous study (Braun et al. 2012) was applied. Briefly, slides were deparaffinised in xylol (for PTGFR in Roti-Histol; Carl Roth $\mathrm{GmbH}$, Karlsruhe, Germany) and rehydrated in ethanol. Antigen retrieval was performed in citrate buffer $(10 \mathrm{mM}$, $\mathrm{pH}$ 6.0). Endogenous peroxidase activity was quenched by incubation in $0.3 \%$ (for PTGFR in $3 \%$ ) $\mathrm{H}_{2} \mathrm{O}_{2}$ with methanol. Afterwards, the slides were incubated in $10 \%$ goat serum (for PTGFR in 5\% BSA in PBS) in order to block non-specific binding sites. Thereafter, the slides were overlaid overnight with canine-specific polyclonal antibodies: guinea pig antiPTGES (1:2500 (Gram et al. 2014, Kautz et al. 2014)), antiPGFS/AKR1C3 (1:750 (Gram et al. 2013) - both custom made by Eurogentec, Seraing, Belgium) - and rabbit anti-PTGER4 (1:750 (Gram et al. 2014); 101775, Cayman Chemical). For the isotype control, slides were incubated with pre-immune guinea pig serum (PTGES, PGFS/AKR1C3) or rabbit IgG irrelevant antibodies I-1000 (PTGER4; all from Vector Laboratories, Inc, Burlingame, CA, USA) at the same dilution as the primary antibodies. The slides were subsequently incubated with biotinylated secondary goat anti-guinea pig IgG BA-7000 antibodies at 1:100 dilution (PTGES, PGFS/AKR1C3) or goat anti-rabbit IgG BA-1000 at 1:100 dilution (PTGER4; all from Vector Laboratories, Burlingame, CA, USA). The signals for PTGES, PTGER4 and PGFS/AKR1C3 were enhanced with the streptavidin-avidin-peroxidase Vectastain ${ }^{\circledR}$ ABC kit (Vector Laboratories, Burlingame, CA, USA). The PTGFR antibody was used at a 1:100 dilution (PGF2 $\alpha \mathrm{R}(\mathrm{H}-55)$, sc-67029; Santa Cruz Biotechnology). For the negative control, PTGFR slides were incubated with blocking solution instead of primary antibody to test for specificity of staining. Slides for PTGFR analysis 
were subsequently incubated with goat anti-rabbit IgG-HRP (K4002; Dako Deutschland GmbH) as secondary antibody. For all slides, the peroxidase activity was finally detected using the Liquid DAB Substrate Kit (Dako North America, Inc, CA, USA). Sections were counterstained with haematoxylin, dehydrated in ethanol and covered with Histokitt (Assistant, Osterode, Germany) or Roti-Histokitt (for PTGFR; Carl Roth $\mathrm{GmbH}$ ) and coverslips. Slides were analysed with an Axioplan microscope combined with a ProgRes C10 plus camera (both Carl Zeiss Microlmaging $\mathrm{GmbH}$ ) and the Cell^P Soft Imaging Software (Olympus Soft Imaging Solutions $\mathrm{GmbH}$, Muenster, Germany).

\section{Intra-luteal hormone studies by enzyme-linked immunosorbent assay}

The homogenisation of luteal tissue and the subsequent hormone extraction was done as described previously for domestic cat (Zschockelt et al. 2014, Amelkina et al. 2015a) and lynx (Carnaby et al. 2012, Zschockelt et al. 2015) CL. Briefly, aliquots of luteal homogenates $(8-68 \mathrm{mg}$ luteal tissue for cats, 9-65 mg luteal tissue for lynxes) were twice extracted with tertbutyl methyl ether (TBME)/petroleum ether (PE) and extracts were eventually dissolved in $40 \%$ methanol. Prostaglandin $E_{2}$ analyses for domestic cats and Eurasian lynxes were carried out using the commercial DetectX High Sensitivity Prostaglandin $\mathrm{E}_{2}$ Enzyme Immunoassay Kit (K018-HX; Arbor Assays, Ann Arbor, MI, USA) according to the manufacturer's protocol. The stated cross-reactivity was as follows: $100 \%$ to $\mathrm{PGE}_{2}, 2 \%$ to $\mathrm{PGF}_{2 \alpha}$ and $<0.1 \%$ to PGFM. Intra- and inter-assay coefficients of variation $(\mathrm{CVs})$ for three biological samples were $7.4 \%$
( $n=20)$ and $10.4 \%(n=15)$, respectively. During our studies, the K018-HX kit has been discontinued and replaced with a PGE 2 Multi-Format Kit (K051-H; Arbor Assays, Ann Arbor, $\mathrm{MI}, \mathrm{USA})$. Therefore, $\mathrm{PGE}_{2}$ analyses for Iberian lynxes were carried out with the new kit. The stated cross-reactivity was, e.g. $100 \%$ to $\mathrm{PGE}_{2}$ and $0.33 \%$ to $\mathrm{PGF}_{2 \alpha}$. Intra- and inter-assay CVs for three biological samples were $7.8 \%(n=20)$ and $8.9 \%$ $(n=17)$, respectively. The determination of intra-luteal $\mathrm{PGF}_{2 \alpha}$ concentrations was carried out in the same extracts, using an in-house PGF $_{2 \alpha}$ enzyme-linked immunosorbent assay (EIA) as described earlier (Dehnhard \& Jewgenow 2013). The PGF $2 \alpha$ antibody was raised in rabbits immunised against $\mathrm{PGF}_{2 \alpha}-\mathrm{BSA}$ and was described to cross-react to $34 \%$ with $\mathrm{PGF}_{1 \alpha}$ and to less than $0.01 \%$ with PGE $_{2}$, PGFM and PGEM (Claus et al. 1990). Intra- and inter-assay CVs for two biological samples were $4.6 \%(n=10)$ and $7.1 \%(n=10)$.

\section{Statistical analysis}

Due to the inherent problems, CL of pregnant domestic cats and endangered Eurasian lynxes were obtained by chance and only few tissue samples became available. By ensuring independence of data, the respective sample sets contained not enough values to perform a normality test. Thus, no statistical analysis was applied and these results were analysed descriptively. Although the number of replicates was limited as well, statistical analysis was possible for non-pregnant domestic cats and Iberian lynxes. The $\mathrm{R}$ software package ( $\mathrm{R}$ : A language and environment for statistical computing, version 2.15.2, Vienna, Austria) was applied (values of $P \leq 0.05$ were considered significant). As the
A

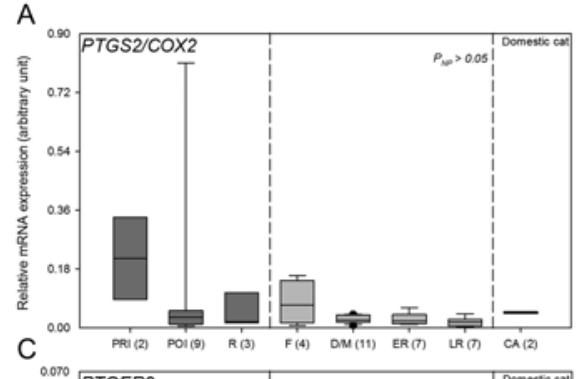

$\mathrm{B}_{20}$

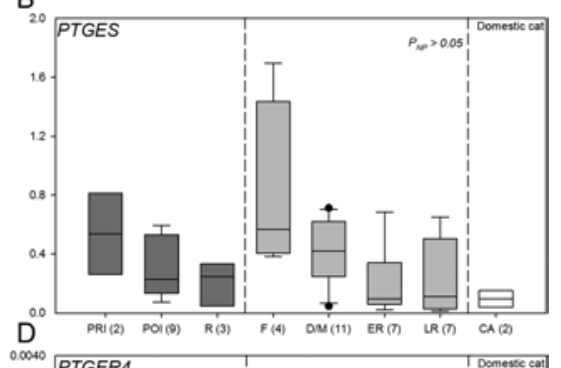

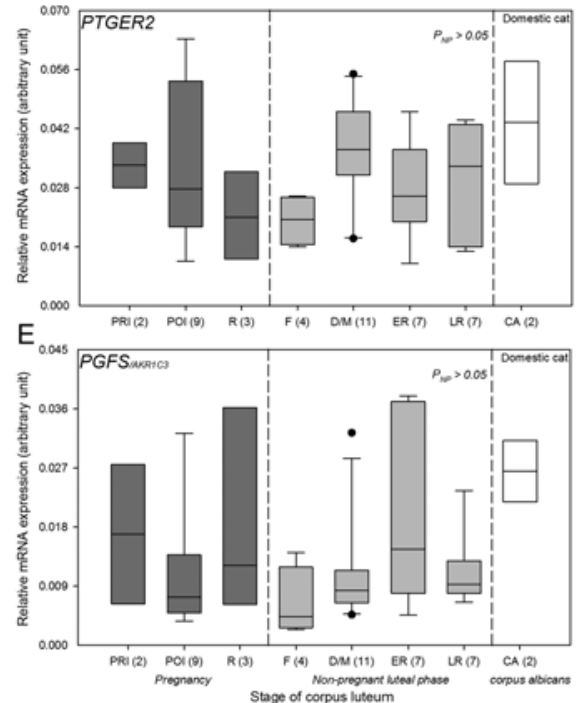

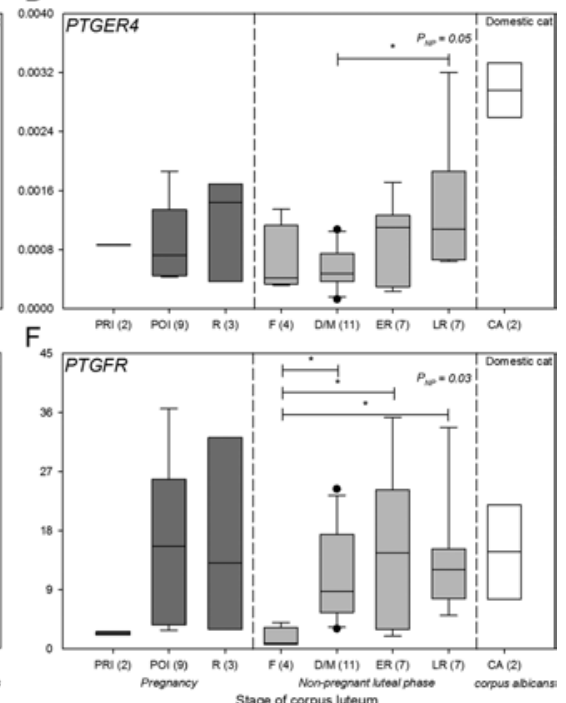

Figure 1 Intra-luteal gene expression of $\mathrm{PGE}_{2}$ and $\mathrm{PGF}_{2 \alpha}$ synthases and receptors in the domestic cat. The PTGS2/COX2 (A), PTGES (B), PTGER2 (C), PTGER4 (D), PGFS/AKR1C3 (E) and PTGFR (F) relative mRNA expression [arbitrary unit] was determined by qPCR (real-time PCR Miner method), normalised with a factor calculated from qPCR results of a reference gene. The Kruskal-Wallis rank sum test was applied for the non-pregnant luteal phase; asterisks indicate statistical differences $\left(P_{N P} \leq 0.05\right)$. Data were plotted per CL stage as $\left(n_{\mathrm{CL}}\right) . \mathrm{CA}$, corpus albicans; $\mathrm{CL}$, corpus luteum; $\mathrm{D} / \mathrm{M}$, development/maintenance; ER, early regression; $F$, formation; $L R$, late regression; $\mathrm{NP}$, non-pregnant luteal phase; POI, postimplantation; PRI, pre-implantation; qPCR, quantitative polymerase chain reaction; $R$, regression. 
distribution of data was not normal, non-parametric statistical methods were used. For non-pregnant domestic cats, the Kruskal-Wallis rank sum test was applied to determine the influence of the CL stage on the relative mRNA expression and hormone levels, followed by the Wilcoxon rank sum test for post hoc pairwise comparison ( $P$-value adjustment: BenjaminiHochberg). For Iberian lynxes, the Mann-Whitney $U$-test was applied to determine the influence of the CL stage on the relative amount of mRNA copies.

The intra-luteal gene expression $\left(n_{\mathrm{CL}}\right)$ and hormone levels $\left(n_{\mathrm{CL}}\right.$ or $\left.n_{\text {animal }} / n_{\mathrm{CL}}\right)$ were depicted in vertical Box Plots plotting data as median and percentiles. The $\mathrm{PGE}_{2}: \mathrm{PGF}_{2 \alpha}$ ratio was depicted as $\left(n_{\mathrm{CL}}\right)$ or $\left(n_{\text {animal }} / n_{\mathrm{CL}}\right)$ in vertical bar charts with simple error bars representing standard deviations (SigmaPlot 10.0, Systat Software GmbH, Erkrath, Germany).

\section{Results}

\section{Intra-luteal gene expression of PGE2 and PGF2 $\alpha$ synthases and receptors}

For the pregnant luteal phase of the domestic cat (no statistical analysis), the qPCR analyses revealed that the medians of relative mRNA expression of PTGS2/ COX2 (Fig. 1A), PTGES (Fig. 1B), PTGER2 (Fig. 1C) and PGFS/AKR1C3 (Fig. 1E) was higher in the preimplantation stage compared with the post-implantation and regression stages. In contrast, for PTGER4 (Fig. 1D) and PTGFR (Fig. 1F), the relative mRNA expression was higher in the regression stage. During the non-pregnant luteal phase (NP; statistical analysis: Kruskal-Wallis rank sum test), the expression of PTCS2/COX2 (Fig. 1A), PTCES (Fig. 1B), PTGER2 (Fig. 1C) and PGFS/AKR1C3 (Fig. 1E) remained unchanged $\left(P_{N P}>0.05\right)$, whereas the expression of PTGER4 ( $P_{N P}=0.05$; Fig. 1D) and PTGFR $\left(P_{N P}=0.03\right.$; Fig. 1F) was affected by the luteal stage. In detail, the expression of PTGER4 was lower in the development/maintenance compared with the late regression stage $\left(P_{N P}=0.035\right)$. For $P T G F R$, the expression was higher in the development/maintenance stage $\left(P_{N P}=0.018\right)$, early regression stage $\left(P_{N P}=0.048\right)$ and late regression stage $\left(P_{N P}=0.018\right)$ compared with the formation stage. The two corpora albicantia exhibited notably high relative mRNA expression for PTGER2 (Fig. 1C), PTGER4 (Fig. 1D) and PGFS/AKR1C3 (Fig. 1E).
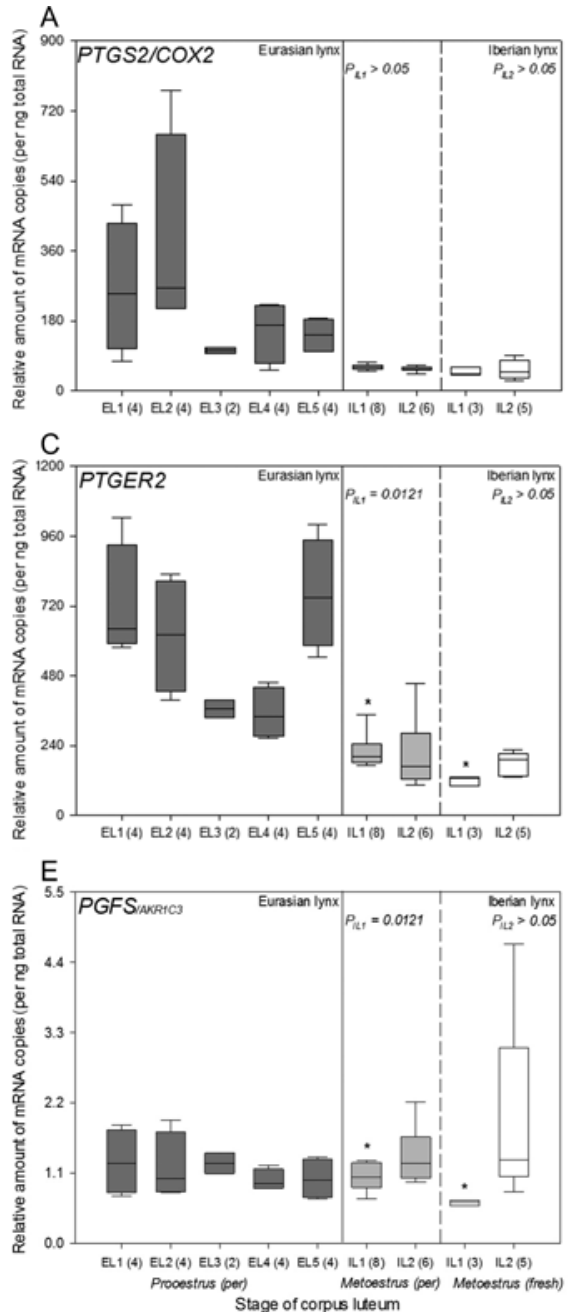

Stage of corpus luteum
B

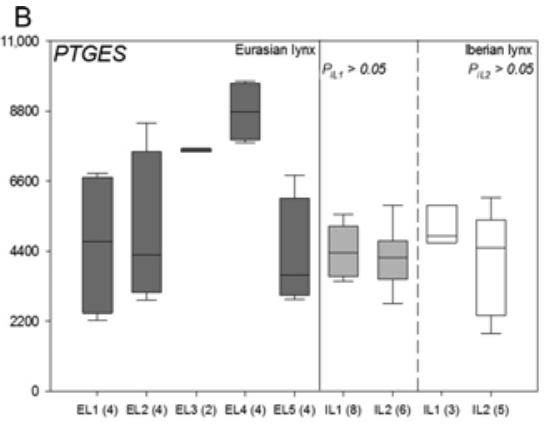

$$
\text { D }
$$

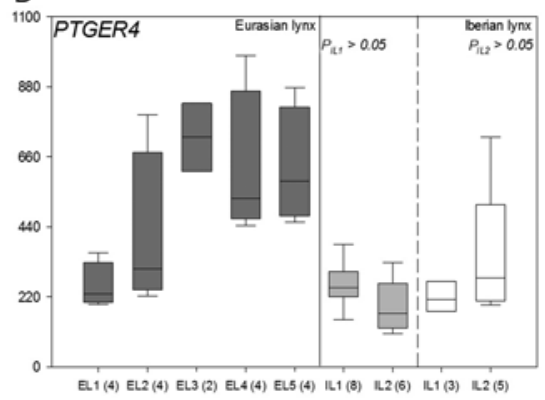

$\mathrm{F}$

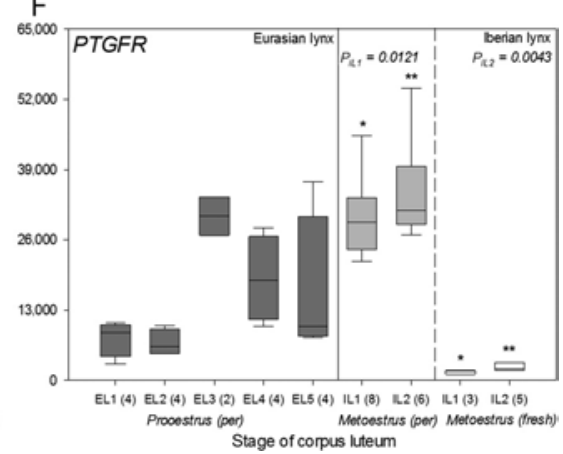

Figure 2 Intra-luteal gene expression of $\mathrm{PGE}_{2}$ and $\mathrm{PGF}_{2 \alpha}$ synthases and receptors in Eurasian and Iberian lynxes. The PTGS2/COX2 (A), PTGES (B), PTGER2 (C), PTGER4 (D), $P G F S / A K R 1 C 3$ (E) and PTGFR (F) relative amount of mRNA copies (per ng total RNA) are copy numbers determined by a calibration curve in qPCR that were afterwards normalised with a factor calculated from qPCR results of reference genes. Values refer to $1 \mathrm{ng}$ original total RNA. The Mann-Whitney $U$-test was applied for the metoestrous Iberian lynxes; asterisks indicate statistical differences $\left(P_{\text {ILI/LL }} \leq 0.05\right)$. Data were plotted per CL stage as $\left(n_{\mathrm{CL}}\right) . \mathrm{CL}$, corpus luteum; EL, Eurasian lynx; fresh, freshly formed CL; IL, Iberian lynx; per, persistent $\mathrm{CL}$; $\mathrm{qPCR}$, quantitative polymerase chain reaction. 
For Iberian lynxes (statistical analysis: MannWhitney U-test), the relative amount of mRNA copies was independent of the luteal stage for PTGS2/COX2 (Fig. 2A), PTGES (Fig. 2B) and PTGER4 (Fig. 2D; for all $\left.P_{\text {ILI/IL2 }}>0.05\right)$. The amount of mRNA for PTGER2 (Fig. 2C) and PGFS/AKR1C3 (Fig. 2E) was higher in metoestrous perCL compared with freshCL in one of the two animals (for both genes: $P_{I L 1}=0.0121 ; P_{I L 2}>0.05$ ). Both animals revealed higher mRNA amounts of PTGFR
(Fig. 2F) in perCL compared with freshCL $\left(P_{I L 1}=0.0121\right.$, $\left.P_{I L 2}=0.0043\right)$. Medians of relative mRNA amounts in perCL of prooestrous Eurasian lynxes (SNO, Norway; no statistical analysis) were equal (PTGES, Fig. 2B; PGFS/ $A K R 1 C 3$, Fig. 2E) or intermediate (PTGFR; Fig. 2F) compared with perCL and freshCL of metoestrous Iberian lynxes. For PTGS2/COX2 (Fig. 2A), PTGER2 (Fig. 2C) and PTGER4 (Fig. 2D), the medians were higher in perCL of Eurasian lynxes. $\begin{array}{llll}\text { A } & \text { PTGES } & \text { B } & \text { PTGER4 }\end{array}$
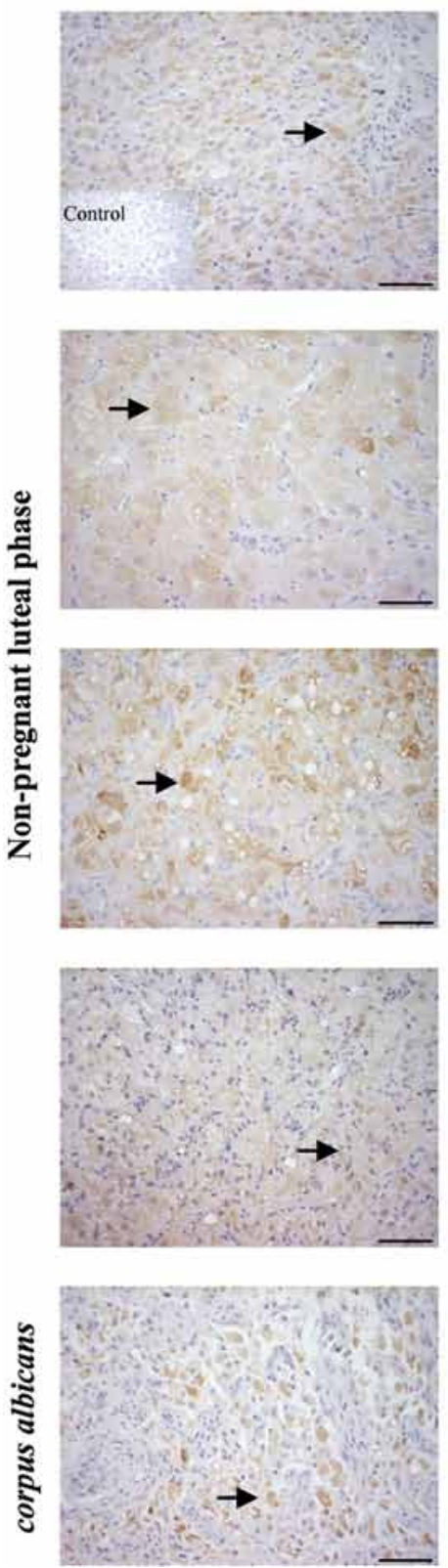

B PTGER4

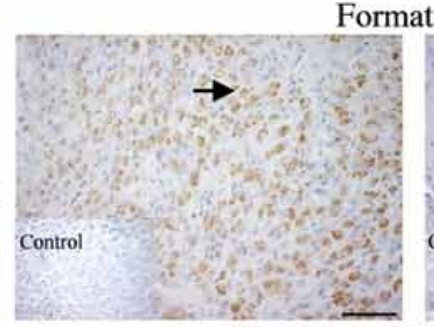

C
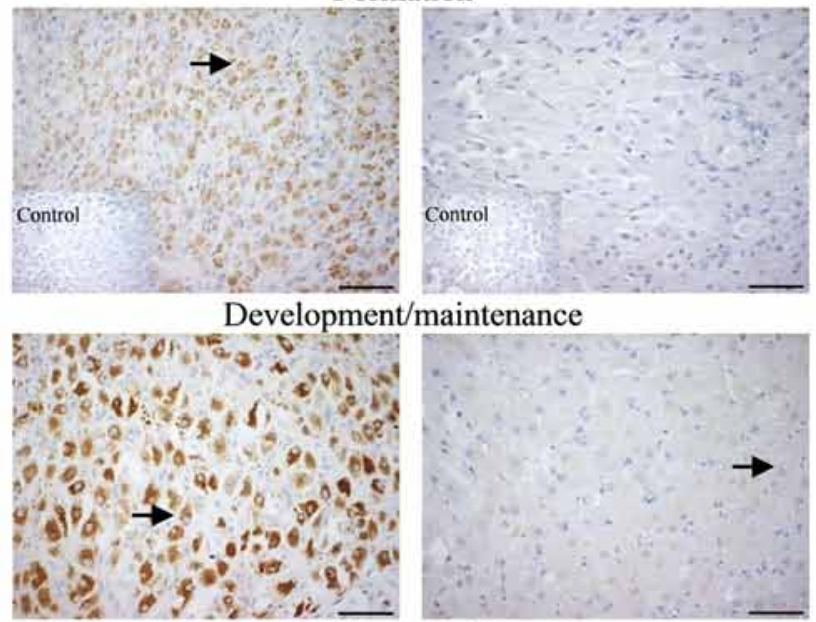

Early regression

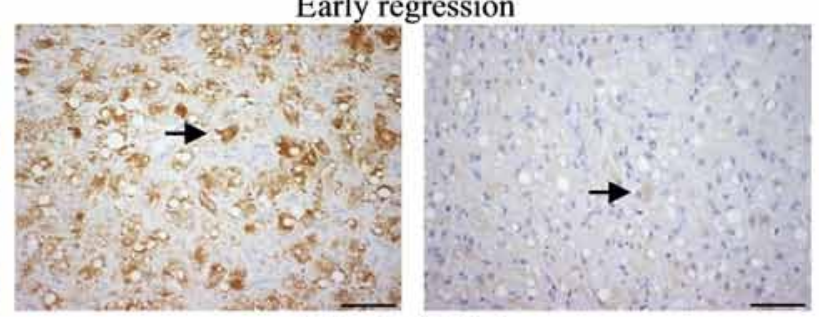

Late regression
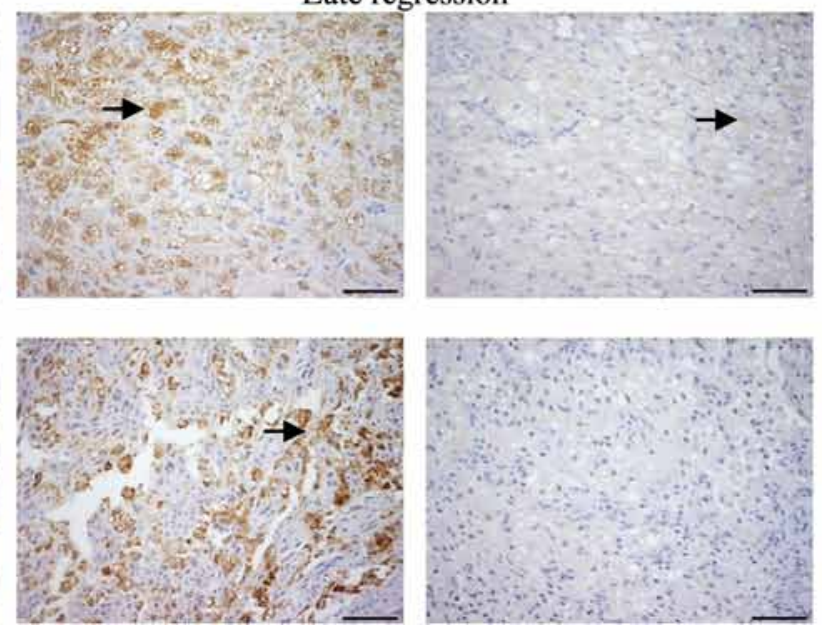

\section{PTGFR}
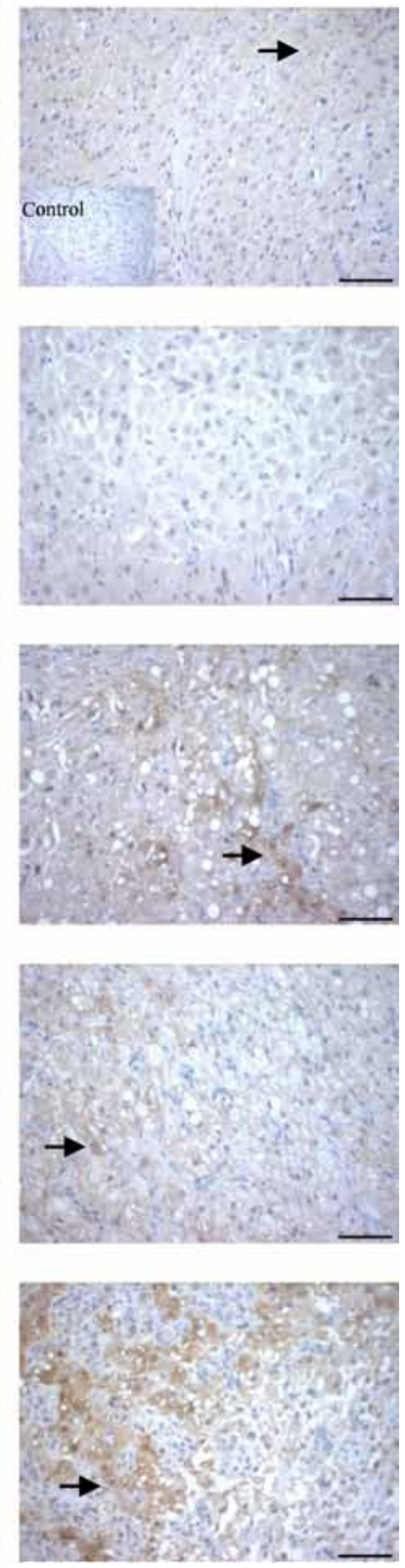

Figure 3 Intra-luteal protein expression of $\mathrm{PGE}_{2}$ and $\mathrm{PGF}_{2 \alpha}$ synthases and receptors in the domestic cat. Protein expression of PTGES (A), PTGER4 (B), PGFS/AKR1C3 (C) and PTGFR (D) was analysed for the non-pregnant luteal phase and in the corpus albicans by immunohistochemistry. Arrows indicate positive staining. Insets show isotype (PTGES, PTGER4, PGFS/AKR1C3) and negative controls (PTGFR). Scale bars represent $50 \mu \mathrm{m}$. 


\section{Cellular localisation and protein expression of PGE2 and PGF2 $\alpha$ synthases and receptors}

As revealed by immunohistochemistry, staining for protein expression of PG synthases and receptors was localised to luteal cells. Throughout the pregnant (data not shown) and the non-pregnant luteal phases of the domestic cat (Fig. 3), clear signals were observed for luteal PTGES (Fig. 3A) and PTGER4 (Fig. 3B). Also, the corpus albicans exhibited prominent staining (Fig. 3A and B). The protein expression of PGFS/AKR1C3 remained constantly low at all time points investigated during pregnancy (data not shown). In non-pregnant cats, no signals for PGFS/AKR1C3 protein expression were found in the formation stage, but weak staining was detected during the development/maintenance stage (Fig. 3C). The signals were then slightly more intense during the early regression and the late regression stages. In the corpus albicans, no signal was detected. The expression of PTGFR was equally strong at days 4, 24 and 48 p.c. in CL of pregnant cats (data not shown). During the non-pregnant phase, expression of PTGFR was weak during the early luteal phase (Fig. 3D), absent in the development/maintenance stage, but clearly evident in the early regression stage, the late regression stage and the corpus albicans.

At prooestrus and metoestrus of Eurasian ( $\mathrm{SNO}$, Norway) and Iberian lynxes, the intensity of the luteal

signal for PTGES (Fig. 4A) and PTGER4 (Fig. 4B) was equally strong between perCL and freshCL. In all analysed lynx $C L$, no signals for PGFS/AKR1C3 protein expression were present (Fig. 4C), but staining for PTGFR was evident (Fig. 4D). The dot-shaped staining detected in perCL of both lynx species stained with different antibodies was considered non-specific, as it was found in control slides as well.

\section{Intra-luteal $\mathrm{PGE}_{2}$ and $\mathrm{PGF}_{2 \alpha}$ concentrations}

Using EIA, it was revealed that the median $\mathrm{PGE}_{2}$ levels measured in $\mathrm{CL}$ of pregnant domestic cats (Fig. 5A; no statistical analysis) decreased from the pre-implantation to the regression stage. The median concentrations of $\mathrm{PGF}_{2 \alpha}$ were numerically higher in the post-implantation and regression stages compared with the pre-implantation stage of pregnancy (Fig. 5B). During the non-pregnant luteal phase (Fig. 5A), the $\mathrm{PGE}_{2}$ level changed $\left(P_{N P}=0.038\right.$; statistical analysis: KruskalWallis rank sum test), but the post hoc test failed to reveal differences between specific groups. In the single corpus albicans sample, a moderate $\mathrm{PGE}_{2}$ concentration was measured $(196.55 \mathrm{ng} / \mathrm{g})$. The intra-luteal $\mathrm{PGF}_{2 \alpha}$ level was unaffected by the luteal stage $\left(P_{N P}>0.05\right.$; Fig. $\left.5 \mathrm{~B}\right)$ for non-pregnant cats. Relatively high $\mathrm{PGF}_{2 \alpha}$ levels were noted for the single corpus albicans available
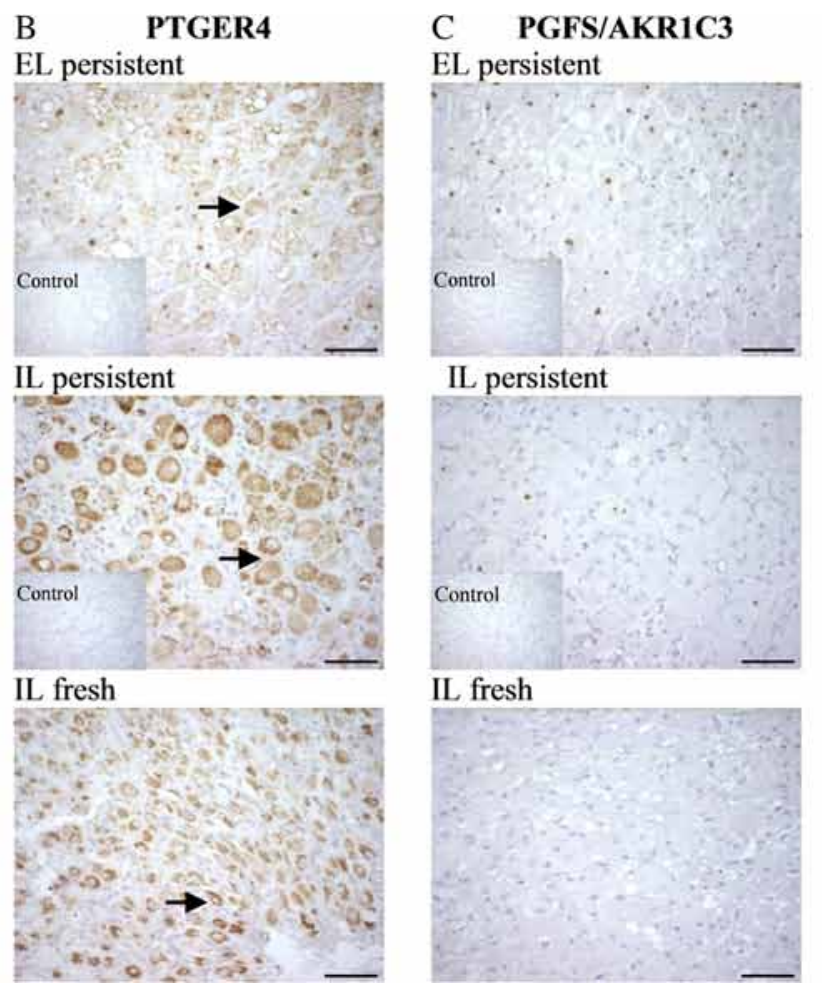

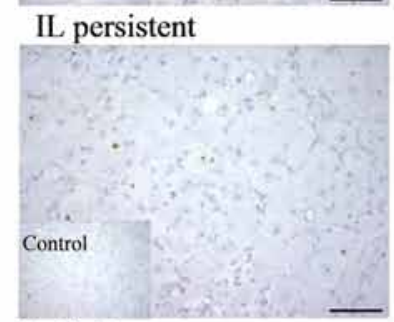

IL fresh

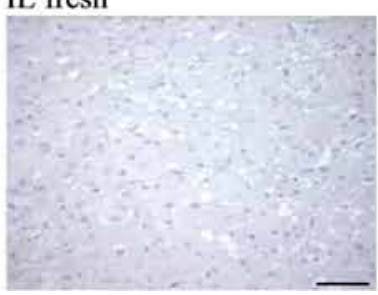

IL fresh
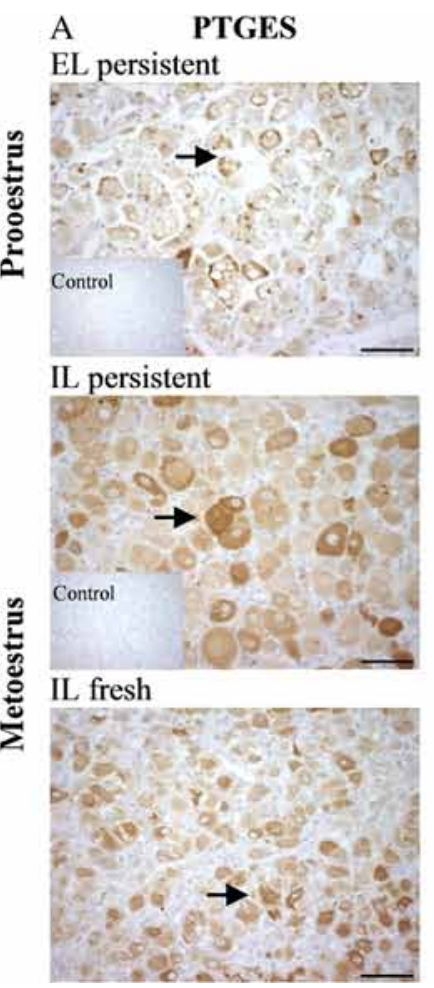
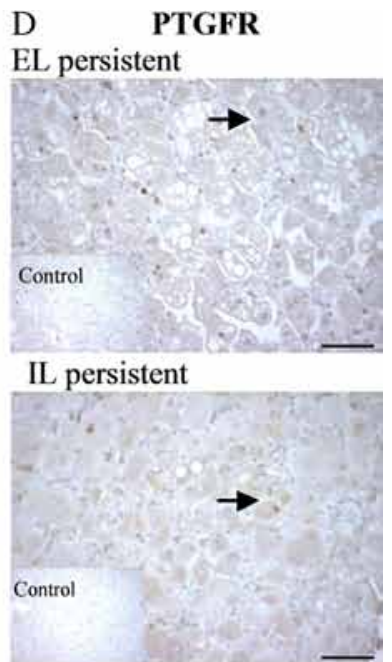

\section{IL fresh}

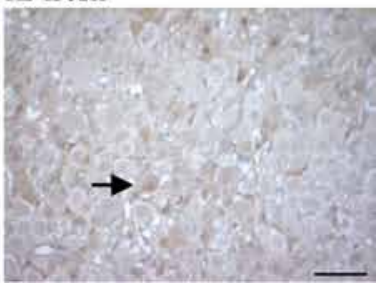

Figure 4 Intra-luteal protein expression of $\mathrm{PGE}_{2}$ and $\mathrm{PGF}_{2 \alpha}$ synthases and receptors in Eurasian and Iberian lynxes. Protein expression of PTGES (A), PTGER4 (B), PGFS/AKR1C3 (C) and PTGFR (D) was analysed for perCL and freshCL of prooestrus and metoestrus by immunohistochemistry. Arrows indicate positive staining. Insets show isotype (PTGES, PTGER4, PGFS/AKR1C3) and negative controls (PTGFR). Scale bars represent $50 \mu \mathrm{m}$. CL, corpus luteum; EL, Eurasian lynx; fresh, freshly formed CL; IL, Iberian lynx; per, persistent CL. 

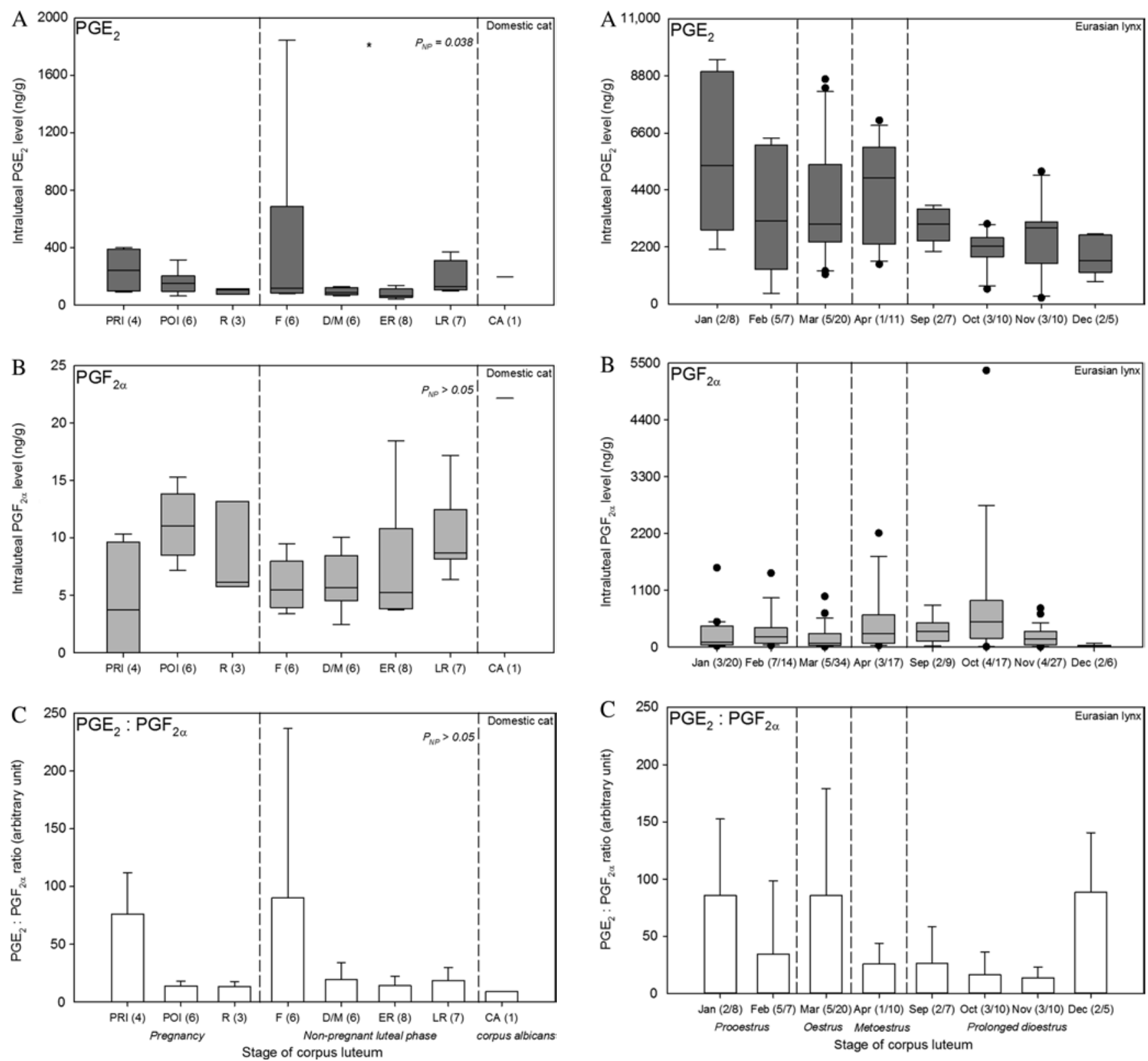

Figure 5 Intra-luteal levels of $\mathrm{PGE}_{2}$ and $\mathrm{PGF}_{2 \alpha}$ in the domestic cat. The $\mathrm{PGE}_{2}(\mathrm{~A})$ and $\mathrm{PGF}_{2 \alpha}$ (B) levels [ng/g tissue] were determined by enzyme-linked immunosorbent assay. The $\mathrm{PGE}_{2}: \mathrm{PGF}_{2 \alpha}$ ratio $(\mathrm{C})$ [arbitrary unit] was calculated by division of $\mathrm{PGE}_{2}$ values by $\mathrm{PGF}_{2 \alpha}$ values. The Kruskal-Wallis rank sum test was applied for the non-pregnant luteal phase; asterisks indicate statistical differences $\left(P_{N P} \leq 0.05\right)$. Data were plotted per $\mathrm{CL}$ stage as $\left(n_{\mathrm{CL}}\right)$. CA, corpus albicans; CL, corpus luteum; D/M, development/maintenance; ER, early regression; $F$, formation; $L R$, late regression; $N P$, non-pregnant luteal phase; POI, post-implantation; PRI, pre-implantation; R, regression.

for the study $(22.17 \mathrm{ng} / \mathrm{g})$. In general, the maximum level of $\mathrm{PGE}_{2}(1845.50 \mathrm{ng} / \mathrm{g}$; formation stage) was considerably higher compared with the maximum level of $\mathrm{PGF}_{2 \alpha}(22.17 \mathrm{ng} / \mathrm{g}$; corpus albicans). In cat $\mathrm{CL}$, the ratio of $\mathrm{PGE}_{2}: \mathrm{PGF}_{2 \alpha}$ was in favour of $\mathrm{PGE}_{2}$ especially at

Figure 6 Intra-luteal levels of $\mathrm{PGE}_{2}$ and $\mathrm{PGF}_{2 \alpha}$ during the annual cycle of Eurasian lynxes. The $\mathrm{PGE}_{2}(\mathrm{~A})$ and $\mathrm{PGF}_{2 \alpha}$ (B) levels (ng/g tissue) were determined by enzyme-linked immunosorbent assay. The $\mathrm{PGE}_{2}: \mathrm{PGF}_{2 \alpha}$ ratio $(\mathrm{C})$ [arbitrary unit] was calculated by division of $\mathrm{PGE}_{2}$ by $\mathrm{PGF}_{2 \alpha}$ values. Data were plotted per month as $\left(n_{\text {animal }} / n_{\mathrm{CL}}\right)$. $\mathrm{CL}$, corpus luteum.

pre-implantation (no statistical analysis), but was constant throughout the non-pregnant luteal phase $\left(P_{N P}>0.05\right.$; Fig. 5C).

During the annual cycle of Eurasian lynxes (SVA, Sweden; Fig. 6A, no statistical analysis), the median levels of intra-luteal $\mathrm{PGE}_{2}$ were high in January $(5334 \mathrm{ng} / \mathrm{g}$; prooestrus) and April (4866.20 ng/g; metoestrus). Low median levels were measured in December (1666.40 ng/g; prolonged dioestrus). The intra-luteal level of $\mathrm{PGF}_{2 \alpha}$ was almost constant throughout the 

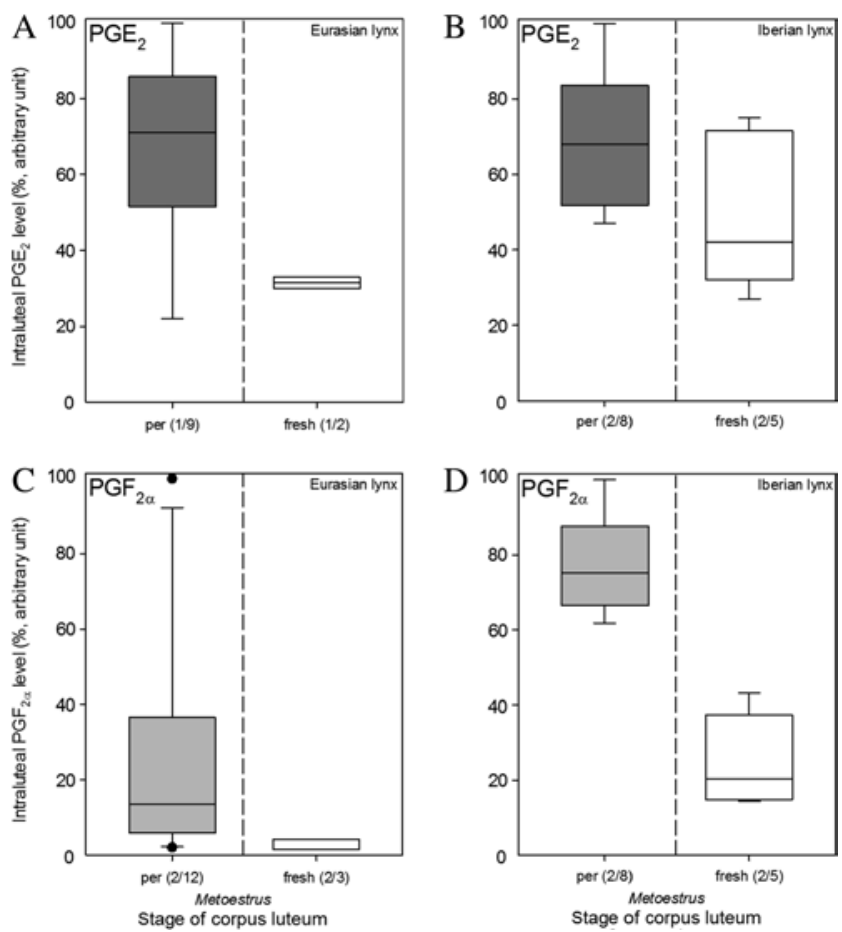

Figure 7 Intra-luteal levels of $\mathrm{PGE}_{2}$ and $\mathrm{PGF}_{2 \alpha}$ in persistent and fresh corpora lutea of metoestrous Eurasian and Iberian lynxes. The $\mathrm{PGE}_{2}$ $(\mathrm{A}$ and $\mathrm{B})$ and $\mathrm{PGF}_{2 \alpha}(\mathrm{C}$ and $\mathrm{D})$ levels [\%, arbitrary unit] were determined by enzyme-linked immunosorbent assay. The hormone levels were put in relation to the respective maximum $\mathrm{PGE}_{2}$ or $\mathrm{PGF}_{2 \alpha}$ value $(=100 \%)$ and were depicted on a percentage basis.

Presentation of arbitrary units became necessary, as different $\mathrm{PGE}_{2}$ enzyme immunoassay kits were used for Eurasian and Iberian lynxes. Data were plotted per CL stage as $\left(n_{\text {animal }} / n_{\mathrm{CL}}\right) . \mathrm{CL}$, corpus luteum; fresh, freshly formed $\mathrm{CL}$; per, persistent $\mathrm{CL}$.

year (Fig. 6B) and median levels ranged from $485 \mathrm{ng} / \mathrm{g}$ (October) to $20.35 \mathrm{ng} / \mathrm{g}$ (December). In Eurasian lynxes, the annual median levels of $\mathrm{PGE}_{2}$ were substantially higher compared with the median levels of $\mathrm{PGF}_{2 \alpha}$. Accordingly, the $\mathrm{PGE}_{2}: \mathrm{PGF}_{2 \alpha}$ ratio revealed prevalence in the direction of $\mathrm{PGE}_{2}$ (no statistical analysis), with higher ratios in January (prooestrus), March (oestrus) and December (prolonged dioestrus; Fig. 6C).

The level of $\mathrm{PGE}_{2}$ and $\mathrm{PGF}_{2 \alpha}$ during metoestrus was further compared between perCL and freshCL of either Eurasian or Iberian lynxes (Fig. 7; no statistical analysis). For both species, the median $\mathrm{PGE}_{2}$ level was numerically higher in perCL than in freshCL (Fig. 7A and $\mathrm{B})$. The median $\mathrm{PGF}_{2 \alpha}$ concentration was higher in perCL compared with freshCL in both lynx species as well (Fig. 7C and D).

\section{Discussion}

This study analysed the intra-luteal $\mathrm{PGE}_{2}$ and $\mathrm{PGF}_{2 \alpha}$ synthesis and reception in relation to the different reproductive strategies of the domestic cat and the two European lynx species. We demonstrated that the feline
$\mathrm{CL}$ is capable of synthesising PGs de novo during the pregnant and non-pregnant luteal phases in cats and at prooestrus and metoestrus of lynxes. While there is a distinct prevalence towards intra-luteal synthesis of $\mathrm{PGE}_{2}$ rather than $\mathrm{PGF}_{2 \alpha^{\prime}}$ a potential receptivity of the feline $C L$ to intra-luteal and extra-luteal $\mathrm{PGE}_{2}$ and $\mathrm{PGF}_{2 \alpha}$ signals is evident.

The $\mathrm{CL}$ of most mammals possesses an inherent capacity to produce PGs which is induced by specific events during the luteal phase (Olofsson \& Leung 1994). The luteal expression of PTCS2/COX2 is increased at the beginning of the $\mathrm{CL}$ phase in dogs (Kowalewski et al. 2006, 2015). Likewise, luteal concentrations of PTCS2/ COX2 mRNA are greater in the early compared with mid and late luteal phases in the cow (Kobayashi et al. 2002). In contrast, the protein content of PTGS2/COX2 is high in the mouse ovary during $\mathrm{CL}$ regression (Sander et al. 2008), and the PTGS2/COX2 expression increases from the early to the late luteal phase in human CL (Mitchell et al. 1991). However, our results demonstrated the steady-state expression of PTGS2/COX2 mRNA in the $\mathrm{CL}$ of cats and lynxes. The constant intra-luteal PTCS2/ COX2 expression neither reflects the functional and structural demise of cat $C L$ at the end of the luteal phases (Zschockelt et al. 2014, Amelkina et al. 2015a) nor the temporarily limited steroidogenic capacity of prooestrous perCL in lynxes (Zschockelt et al. 2015). However, it must be considered that expression on the mRNA level not necessarily reflects expression on the protein level. As no specific antibody was available, the expression pattern of PTGS2/COX2 remains subject for further studies.

The selective production of PGs is generally in favour of $\mathrm{PGE}_{2}$ rather than $\mathrm{PGF}_{2 \alpha}$ during luteal development in different species (Vijayakumar \& Walters 1983, Olofsson et al. 1992). For example, in the bovine and canine $\mathrm{CL}, \mathrm{PGE}_{2}$ synthesis is particularly evident during the phase of luteal formation, likely being involved in $\mathrm{CL}$ development and growth (Arosh et al. 2004, Kowalewski et al. 2015). Similar to other species (Vijayakumar \& Walters 1983, Olofsson et al. 1992, Miller \& Pawlak 1994), and in accordance with the confirmed presence of PTGES mRNA and protein, $\mathrm{PGE}_{2}$ was the predominant PG measurable in feline luteal tissue, with high concentrations throughout the pregnant and nonpregnant luteal phases of the cat and during the annual cycle of Eurasian lynxes. For $\mathrm{PGE}_{2}$, several receptors have been described with PTGER2 and PTGER4 being relevant for protecting the $\mathrm{CL}$ from luteolytic challenges during early pregnancy in sheep (Lee et al. 2012), and PTGER2 being responsible for stimulation of $\mathrm{P} 4$ production via regulation of luteal 11 betaHSD1 activity in humans (Chandras et al. 2007). In cattle (Arosh et al. 2004) and dioestrous dogs (Kowalewski et al. 2008a), PTGER2 mRNA exhibited highest expression in the growing $\mathrm{CL}$, whereas in pregnant dogs, PTGER2 declined pre-partum (Kowalewski et al. 2013). PTGER4 showed a constant 
expression pattern during the canine luteal lifespan (Kowalewski et al. 2008a, 2013). The results of our study imply that reception of $\mathrm{PGE}_{2}$ in the feline $\mathrm{CL}$ is mainly independent of the luteal and reproductive stages, suggesting an autocrine/paracrine luteotrophic effect of $\mathrm{PGE}_{2}$ on the $\mathrm{CL}$ maintenance. Sufficient prevention of $\mathrm{CL}$ regression by high intra-luteal $\mathrm{PGE}_{2}$ levels would be in accordance with the resistance of early cat $C L$ to exogenous $\mathrm{PGF}_{2 \alpha}$ given on days 4 and 5 or 12 and 13 p.c., which has no effect on circulating P4 levels and the CL size (Wildt et al. 1979).

The confirmed high expression of $\mathrm{PGE}_{2}$ receptors in $\mathrm{CL}$ of lynxes, together with substantial annual intra-luteal $\mathrm{PGE}_{2}$ contents, might be one of the crucial intra-luteal mechanisms fulfilling the luteotrophic requirements for refractoriness of lynx CL to complete structural regression. Our remarkable finding that perCL of Eurasian and Iberian lynxes contain higher intra-luteal $\mathrm{PGE}_{2}$ levels than freshCL might bring forth a new hypothesis on the luteotrophic role of $\mathrm{PGE}_{2}$ in the functional and structural persistence of lynx CL. The luteotrophic action of $\mathrm{PGE}_{2}$ might support the maintained steroidogenic activity of perCL outside the breeding season in Eurasian (Carnaby et al. 2012, Painer et al. 2014b) and Iberian lynxes (Zschockelt et al. 2015). This is most likely associated with elevated serum P4 levels throughout the year, which is presumed to ensure a monooestrous cycle by preventing folliculogenesis and ovulation (Göritz et al. 2009, Painer et al. 2014b). In addition, and according to our previous hypothesis on perCL as a supplemental source of P4 (Zschockelt et al. 2015), our present findings on high intra-luteal $\mathrm{PGE}_{2}$ synthesis might propose the luteotrophic support of freshCL (P4 synthesis) by CL of previous years (Woshner et al. 2001, Jewgenow et al. 2014). Direct evidence for this suggested intra-ovarian and paracrine mechanism merits further investigations.

Changes in the ratio of potentially luteotrophic $\mathrm{PGE}_{2}$ and luteolytic $\mathrm{PGF}_{2 \alpha}$ throughout the luteal phase seems to be of major functional relevance. In general, synthesis of luteolytic $\mathrm{PGF}_{2 \alpha}$ by the $\mathrm{CL}$ is shifted towards the late luteal phase (Wiltbank \& Ottobre 2003). Luteal $\mathrm{PGF}_{2 \alpha}$ levels increase at the expense of $\mathrm{PGE}_{2}$ during luteal regression in mice (Sander et al. 2008). Similarly, $\mathrm{PGF}_{2 \alpha}$ production in pigs rises from the mid to the late luteal phase (Patek \& Watson 1976). Interestingly, the capacity of the feline $\mathrm{CL}$ to provide $\mathrm{PGF}_{2 \alpha}$ was limited and in agreement with low mRNA expression of PGFS/ AKR1C3; only weak protein signals for PGFS/AKR1C3 were detected at some $C L$ stages of cats, but no signals were found in $\mathrm{CL}$ of lynxes. During pregnancy and dioestrus in dogs, only weak or no intra-luteal PGFS/ AKR1C3 expression was detectable as well (Kowalewski et al. 2008b, Gram et al. 2013). We conclude that the local luteal production of $\mathrm{PGF}_{2 \alpha}$ is presumably not involved in the initiation of the onset of pre-partal and non-pregnant luteal regression in felids. In lynxes, CL persist for at least two years (Painer et al. 2014b) and retain their structural integrity (Jewgenow et al. 2012, Amelkina et al. 2015b). Thus, the general assumption that functional luteal regression, as initiated by extraluteal $\mathrm{PGF}_{2 \alpha^{\prime}}$ precedes structural luteal regression by intra-luteal amplification of the luteolytic signal (Diaz et al. 2002, Hayashi et al. 2003), might not fully account for perCL in lynxes, in which the absence of an internal $\mathrm{PGF}_{2 \alpha}$ signal might prevent final initiation of the CL demise.

Our results imply that the capacity of feline $C L$ to respond to $\mathrm{PGF}_{2 \alpha}$ via expression of PTGFR is already acquired after $\mathrm{CL}$ formation, but is mainly independent of the luteal stage thereafter, suggesting that luteal regression is triggered by extra-luteal $\mathrm{PGF}_{2 \alpha}$. A change in receptivity towards $\mathrm{PGF}_{2 \alpha}$ was observed only for non-pregnant cats, in which clear signals of PTGFR protein expression were first evident from early regression onwards. Similarly, PTGFR mRNA levels increase from the early to the mid luteal phase in the cow (Arosh et al. 2004), rabbit (Boiti et al. 2001), pig (Boonyaprakob et al. 2003) and dog (Kowalewski et al. 2008b, 2009). However, in non-pregnant felids, any (external) pregnancy-specific luteolytic signal is missing. For example, in lynxes, neither intra-luteal (this study), faecal and urinary (Finkenwirth et al. 2010, Dehnhard et al. 2012) nor plasma (Painer et al. 2014b) levels show changes in $\mathrm{PGF}_{2 \alpha}$ or PGFM profiles, suggesting that the non-pregnant luteal regression is not actively regulated by luteal or endometrial $\mathrm{PGF}_{2 \alpha}$. In contrast, for preterm cats, the placenta appears to be one of the main sources of $\mathrm{PGF}_{2 \alpha \prime}$ as placental $\mathrm{PGF}_{2 \alpha}$ and its plasma metabolite PGFM are elevated during the last trimester of pregnancy (Siemieniuch et al. 2014). Related to this, only during the late pregnancy, $\mathrm{PGF}_{2 \alpha}$ seems to play a physiological luteolytic role in felids, i.e. luteotrophic support of CL maintenance might be actively curtailed prior parturition by high expression of PTGFR.

In prooestrous lynxes, expression of PTGFR was present in luteal cells of perCL. However, PGF $2 \alpha$ of luteal origin is not responsible for signs of early luteal regression in these lynxes and onset of oestrus is not reflected in urinary and faecal PGFM profiles (Finkenwirth et al. 2010, Dehnhard et al. 2012). Moreover, despite artificially induced regression with cloprostenol (a PGF $2 \alpha$ analogue) outside the breeding season, perCL are preserved in structure for at least two subsequent years and the ovarian blood supply and steroid production reconstitute (Painer et al. 2014a,b). Interestingly, also during metoestrus, perCL retain their functional and structural integrity while still expressing receptors for potentially luteolytic $\mathrm{PGF}_{2 \alpha}$. It might be hypothesised that next to the lack of a substantial endogenous luteolytic $\mathrm{PGF}_{2 \alpha}$ signal, the preservation of the CL structure is further caused by an interference of anti-apoptotic (pro-survival) factors which inhibit transmission of any luteolytic signal via the apoptotic cascade (Amelkina et al. 2015b). Thus, despite 
expression of PTGFR, the final structural CL demise is prevented and structural integrity is prolonged in lynxes, suggesting that any inherent regression programme, if existent, is not executed as proposed for the cat.

In conclusion, our data implicate a potential role of $\mathrm{PGE}_{2}$ in maintaining $\mathrm{CL}$ persistence in lynxes, thus ensuring their atypical ovarian cycle compared with other felids. Factors that induce the temporal functional luteal regression prior a new breeding season are yet to be identified. To emphasise our hypotheses based on the currently available sample set, additional data are required which is complicated by the conservation status of the analysed species. The observations are therefore limited to the system of the presented animals and do not account for animal-specific individual variations. Although it is difficult to draw more solid conclusions, the present study is an essential prerequisite to develop suitable techniques of artificial ovulation induction for endangered Iberian lynxes.

\section{Declaration of interest}

The authors declare that there is no conflict of interest that could be perceived as prejudicing the impartiality of the research reported.

\section{Funding}

This work was supported by the German Research Foundation (DFG Je 163/11-1), the German Academic Exchange Service (DAAD A/10/86242, D/12/42001) and the Polish Ministry of Scientific Research and High Education (MNiSW IP2011 048971).

\section{Acknowledgements}

We thank Elisabeth Högger, Sigrid Holz, Katrin Paschmionka, Susanne Pribbenow, Anna Z Szóstek and Franka Thiesen for technical assistance. Iberian lynx samples were provided by the Environmental Council of the Government of Andalusia and the ILCBP - we thank Astrid Vargas, Rodrigo Serra and Francisco Villaespesa for their close collaboration. We thank the Statens Naturoppsyn with Johan Schulze for access to and Johanna Painer for collection of Norwegian Eurasian lynx samples. We appreciate provision of Eurasian lynx samples by Arne Söderberg from the Statens Veterinärmedicinska Anstalt. We thank Barry Bavister for English editing of the manuscript.

\section{References}

Amelkina O, Braun BC, Dehnhard M \& Jewgenow K 2015a The corpus luteum of the domestic cat: histologic classification and intraluteal hormone profile. Theriogenology 83 711-720. (doi:10.1016/j. theriogenology.2014.11.008)

Amelkina O, Zschockelt L, Painer J, Serra R, Villaespesa F, Braun BC \& Jewgenow K 2015b Apoptosis-related factors in the luteal phase of the domestic cat and their involvement in the persistence of corpora lutea in lynx. PLOS ONE 10 e0143414. (doi:10.1371/journal.pone.0143414)
Arosh JA, Banu SK, Chapdelaine P, Madore E, Sirois J \& Fortier MA 2004 Prostaglandin biosynthesis, transport, and signaling in corpus luteum: a basis for autoregulation of luteal function. Endocrinology 145 2551-2560. (doi:10.1210/en.2003-1607)

Boiti C, Zampini D, Zerani M, Guelfi G \& Gobbetti A 2001 Prostaglandin receptors and role of $G$ protein-activated pathways on corpora lutea of pseudopregnant rabbit in vitro. Journal of Endocrinology 168 141-151. (doi:10.1677/joe.0.1680141)

Boonyaprakob U, Gadsby JE, Hedgpeth V, Routh P \& Almond GW 2003 Cloning of pig prostaglandin F2alphaFP receptor cDNA and expression of its mRNA in the corpora lutea. Reproduction 125 53-64. (doi:10.1530/ rep.0.1250053)

Braun BC, Vargas A \& Jewgenow K 2012 The molecular detection of relaxin and its receptor RXFP1 in reproductive tissue of Felis catus and Lynx pardinus during pregnancy. Reproduction 143 399-410. (doi:10.1530/ REP-11-0316)

Carnaby K, Painer J, Soderberg A, Gavier-Widen D, Goritz F, Dehnhard M \& Jewgenow K 2012 Histological and endocrine characterisation of the annual luteal activity in Eurasian lynx (Lynx lynx). Reproduction 144 477-484. (doi:10.1530/REP-12-0166)

Chandras C, Harris TE, Bernal AL, Abayasekara DR \& Michael AE 2007 PTGER1 and PTGER2 receptors mediate regulation of progesterone synthesis and type 1 11beta-hydroxysteroid dehydrogenase activity by prostaglandin E2 in human granulosa lutein cells. Journal of Endocrinology 194 595-602. (doi:10.1677/JOE-07-0128)

Claus R, Meyer HD, Gimenez T, Hoangvu C \& Munster E 1990 Effect of seminal estrogens of the boar on prostaglandin-F2-alpha release from the uterus of the sow. Animal Reproduction Science 23 145-156. (doi:10.1016/0378-4320(90)90056-L)

Dawson AB 1946 The postpartum history of the corpus luteum of the cat. Anatomical Record 95 29-51. (doi:10.1002/(ISSN)1097-0185)

Dehnhard M \& Jewgenow K 2013 Measurement of faecal prostaglandins in felids and three ursid species. Wiener Tierarztliche Monatsschrift 100 227-237.

Dehnhard M, Finkenwirth C, Crosier A, Penfold L, Ringleb J \& Jewgenow K 2012 Using PGFM (13,14-dihydro-15-keto-prostaglandin F2alpha) as a non-invasive pregnancy marker for felids. Theriogenology 77 1088-1099. (doi:10.1016/j.theriogenology.2011.10.011)

Diaz FJ, Anderson LE, Wu YL, Rabot A, Tsai SJ \& Wiltbank MC 2002 Regulation of progesterone and prostaglandin F2alpha production in the CL. Molecular and Cellular Endocrinology 191 65-80. (doi:10.1016/ S0303-7207(02)00056-4)

Fanson KV, Wielebnowski NC, Shenk TM, Vashon JH, Squires JR \& Lucas JR 2010 Patterns of ovarian and luteal activity in captive and wild Canada lynx (Lynx canadensis). General and Comparative Endocrinology 169 217-224. (doi:10.1016/j.ygcen.2010.09.003)

Finkenwirth C, Jewgenow K, Meyer HH, Vargas A \& Dehnhard M 2010 PGFM (13,14-dihydro-15-keto-PGF(2alpha)) in pregnant and pseudo-pregnant Iberian lynx: a new noninvasive pregnancy marker for felid species. Theriogenology 73 530-540. (doi:10.1016/j. theriogenology.2009.10.008)

Göritz F, Dehnhard M, Hildebrandt TB, Naidenko SV, Vargas A, Martinez F, Lopez-Bao JV, Palomares F \& Jewgenow K 2009 Non cat-like ovarian cycle in the Eurasian and the Iberian lynx - ultrasonographical and endocrinological analysis. Reproduction in Domestic Animals 44 87-91. (doi:10.1111/j.1439-0531.2009.01380.x)

Gram A, Buchler U, Boos A, Hoffmann B \& Kowalewski MP 2013 Biosynthesis and degradation of canine placental prostaglandins: prepartum changes in expression and function of prostaglandin F2alpha-synthase (PGFS, AKR1C3) and 15-hydroxyprostaglandin dehydrogenase (HPGD). Biology of Reproduction 89 2. (doi:10.1095/ biolreprod.113.109918)

Gram A, Fox B, Buchler U, Boos A, Hoffmann B \& Kowalewski MP 2014 Canine placental prostaglandin E2 synthase: expression, localization, and biological functions in providing substrates for prepartum PGF2alpha synthesis. Biology of Reproduction 91 154. (doi:10.1095/ biolreprod.114.122929)

Hayashi K, Acosta TJ, Berisha B, Kobayashi S, Ohtani M, Schams D \& Miyamoto A 2003 Changes in prostaglandin secretion by the regressing bovine corpus luteum. Prostaglandins \& Other Lipid Mediators 70 339-349.

Jewgenow K, Amelkina O, Painer J, Goritz F \& Dehnhard M 2012 Life cycle of feline Corpora lutea: histological and intraluteal hormone 
analysis. Reproduction in Domestic Animals 47 25-29. (doi:10.1111/ rda.12033)

Jewgenow K, Painer J, Amelkina O, Dehnhard M \& Goeritz F 2014 Lynx reproduction - long-lasting life cycle of corpora lutea in a feline species. Reproductive Biology 14 83-88. (doi:10.1016/j.repbio.2014.03.002)

Jursza E, Skarzynski DJ \& Siemieniuch MJ 2014 Validation of reference genes in the feline endometrium. Reproductive Biology 14 302-306. (doi:10.1016/j.repbio.2014.04.003)

Kautz E, Gram A, Aslan S, Ay SS, Selcuk M, Kanca H, Koldas E, Akal E, Karakas K, Findik M et al. 2014 Expression of genes involved in the embryo-maternal interaction in the early-pregnant canine uterus. Reproduction 147 703-717. (doi:10.1530/REP-13-0648)

Knospe C 2002 Periods and stages of the prenatal development of the domestic cat. Anatomia, Histologia, Embryologia 31 37-51. (doi:10.1046/j.1439-0264.2002.00360.x)

Kobayashi S, Acosta TJ, Hayashi K, Berisha B, Ozawa T, Ohtani M, Schams D \& Miyamoto A 2002 Intraluteal release of prostaglandin F-2 alpha and E-2 during corpora lutea development in the cow. Journal of Reproduction and Development 48 583-590. (doi:10.1262/jrd.48.583)

Kotwica J, Skarzynski D, Mlynarczuk J \& Rekawiecki R 2003 Role of prostaglandin E2 in basal and noradrenaline-induced progesterone secretion by the bovine corpus luteum. Prostaglandins \& Other Lipid Mediators 70 351-359.

Kowalewski MP, Schuler G, Taubert A, Engel E \& Hoffmann B 2006 Expression of cyclooxygenase 1 and 2 in the canine corpus luteum during diestrus. Theriogenology 66 1423-1430. (doi:10.1016/j. theriogenology.2006.01.039)

Kowalewski MP, Mutembei HM \& Hoffmann B 2008a Canine prostaglandin E2 synthase (PGES) and its receptors (EP2 and EP4): expression in the corpus luteum during dioestrus. Animal Reproduction Science 109 319-329.

Kowalewski MP, Mutembei HM \& Hoffmann B 2008b Canine prostaglandin F2alpha receptor (FP) and prostaglandin F2alpha synthase (PGFS): molecular cloning and expression in the corpus luteum. Animal Reproduction Science 107 161-175.

Kowalewski MP, Beceriklisoy HB, Aslan S, Agaoglu AR \& Hoffmann B 2009 Time related changes in luteal prostaglandin synthesis and steroidogenic capacity during pregnancy, normal and antiprogestin induced luteolysis in the bitch. Animal Reproduction Science 116 129-138. (doi:10.1016/j. anireprosci.2008.12.011)

Kowalewski MP, Fox B, Gram A, Boos A \& Reichler I 2013 Prostaglandin $\mathrm{E}-2$ functions as a luteotrophic factor in the dog. Reproduction 145 213-226. (doi:10.1530/REP-12-0419)

Kowalewski MP, Ihle S, Siemieniuch MJ, Gram A, Boos A, Zdunczyk S, Fingerhut J, Hoffmann B, Schuler G, Jurczak A et al. 2015 Formation of the early canine $\mathrm{CL}$ and the role of prostaglandin E2 (PGE2) in regulation of its function: An in vivo approach. Theriogenology 83 1038-1047. (doi:10.1016/j.theriogenology.2014.12.006)

Kvam T 1991 Reproduction in the European Lynx, Lynx-Lynx. Zeitschrift Fur Saugetierkunde-International Journal of Mammalian Biology $\mathbf{5 6}$ 146-158.

Lawler DF, Johnston SD, Hegstad RL, Keltner DG \& Owens SF 1993 Ovulation without cervical stimulation in domestic cats. Journal of Reproduction and Fertility. Supplement 47 57-61.

Lee J, McCracken JA, Stanley JA, Nithy TK, Banu SK \& Arosh JA 2012 Intraluteal prostaglandin biosynthesis and signaling are selectively directed towards PGF2alpha during luteolysis but towards PGE2 during the establishment of pregnancy in sheep. Biology of Reproduction 8797. (doi:10.1095/biolreprod.112.100438)

Leiser R 1979 [Blastocyst implantation in the domestic cat. Light and electron microscopic study]. Anatomia, Histologia, Embryologia 8 79-96. (doi:10.1111/j.1439-0264.1979.tb00681.x)

Marsh JM \& LeMaire WJ 1974 Cyclic AMP accumulation and steroidogenesis in the human corpus luteum: effect of gonadotropins and prostaglandins. Journal of Clinical Endocrinology and Metabolism 38 99-106. (doi:10.1210/jcem-38-1-99)

McCracken JA, Custer EE \& Lamsa JC 1999 Luteolysis: a neuroendocrinemediated event. Physiological Reviews 79 263-323.

McLean MP, Billheimer JT, Warden KJ \& Irby RB 1995 Prostaglandin F2 alpha mediates ovarian sterol carrier protein-2 expression during luteolysis. Endocrinology $1364963-4972$.

Miller JB \& Pawlak CM 1994 Characterization and physiological variation in prostaglandin, prostacyclin and thromboxane synthesis by corpora lutea, non-luteal and uterine tissues during pseudopregnancy in the rabbit. Life Sciences $\mathbf{5 4}$ 341-353. (doi:10.1016/00243205(94)00790-X)

Mitchell DE, Lei ZM \& Rao CV 1991 The enzymes in cyclooxygenase and lipoxygenase pathways of arachidonic acid metabolism in human corpora lutea: dependence on luteal phase, cellular and subcellular distribution. Prostaglandins, Leukotrienes, and Essential Fatty Acids 43 1-12. (doi:10.1016/0952-3278(91)90125-O)

Nagle CA, Mendizabal AF, Lahoz MM, Porta MM \& Torres MI 2005 Transfer pathways between the ovaries and the uterus in the cebus monkeys (Cebus apella). General and Comparative Endocrinology 144 248-256. (doi:10.1016/j.ygcen.2005.06.006)

Niswender GD, Juengel JL, McGuire WJ, Belfiore CJ \& Wiltbank MC 1994 Luteal function: the estrous cycle and early pregnancy. Biology of Reproduction 50 239-247. (doi:10.1095/biolreprod50.2.239)

Niswender GD, Juengel JL, Silva PJ, Rollyson MK \& McIntush EW 2000 Mechanisms controlling the function and life span of the corpus luteum. Physiological Reviews 80 1-29.

Olofsson J \& Leung PC 1994 Auto/paracrine role of prostaglandins in corpus luteum function. Molecular and Cellular Endocrinology 100 87-91. (doi:10.1016/0303-7207(94)90284-4)

Olofsson J, Norjavaara E \& Selstam G 1992 Synthesis of prostaglandin F2 alpha, E2 and prostacyclin in isolated corpora lutea of adult pseudopregnant rats throughout the luteal life-span. Prostaglandins, Leukotrienes, and Essential Fatty Acids 46 151-161. (doi:10.1016/09523278(92)90222-5)

Paape SR, Shille VM, Seto H \& Stabenfeldt GH 1975 Luteal activity in the pseudopregnant cat. Biology of Reproduction 13 470-474. (doi:10.1095/ biolreprod13.4.470)

Painer J, Goeritz F, Dehnhard M, Hildebrandt TB, Naidenko SV, Sanchez I, Quevedo Munoz MA \& Jewgenow K 2014a Hormoneinduced luteolysis on physiologically persisting corpora lutea in Eurasian and Iberian lynx (Lynx lynx and Lynx pardinus). Theriogenology 82 557-562.

Painer J, Jewgenow K, Dehnhard M, Arnemo JM, Linnell JD, Odden J, Hildebrandt TB \& Goeritz F 2014b Physiologically persistent Corpora lutea in Eurasian lynx (Lynx lynx) - Iongitudinal ultrasound and endocrine examinations intra-vitam. PLOS ONE 9 e90469.

Palomares F, Revilla E, Calzada J, Fernandez N \& Delibes M 2005 Reproduction and pre-dispersal survival of Iberian lynx in a subpopulation of the Donana National Park. Biological Conservation 122 53-59. (doi:10.1016/j.biocon.2004.06.020)

Parker GR \& Smith GEJ 1983 Sex-specific and age-specific reproductive and physical parameters of the bobcat (Lynx-Rufus) on Cape-Breton Island, Nova-Scotia. Canadian Journal of Zoology 61 1771-1782. (doi:10.1139/z83-229)

Patek CE \& Watson J 1976 Prostaglandin F and progesterone secretion by porcine endometrium and corpus luteum in vitro. Prostaglandins $\mathbf{1 2}$ 97-111. (doi:10.1016/S0090-6980(76)80009-3)

Sander VA, Piehl L, Facorro GB, Rubin de Celis E \& Motta AB 2008 Regulation of functional and regressing stages of corpus luteum development in mice. Role of reactive oxygen species. Reproduction, Fertility, and Development 20 760-769. (doi:10.1071/RD08051)

Schnorr B \& Kressin M 2006 Altersbeurteilung der Frucht. In Embryologie der Haustiere, p 82. Stuttgart, Germany: Enke Verlag.

Siemieniuch MJ, Mlynarczuk JJ, Skarzynski DJ \& Okuda K 2011 Possible involvement of oxytocin and its receptor in the local regulation of prostaglandin secretion in the cat endometrium. Animal Reproduction Science 123 89-97. (doi:10.1016/j.anireprosci.2010.10.015)

Siemieniuch MJ, Jursza E, Szostek AZ, Skarzynski DJ, Boos A \& Kowalewski MP 2012 Steroidogenic capacity of the placenta as a supplemental source of progesterone during pregnancy in domestic cats. Reproductive Biology and Endocrinology 10 89. (doi:10.1186/14777827-10-89)

Siemieniuch MJ, Jursza E, Kowalewski MP, Majewska M \& Skarzynski DJ 2013 Prostaglandin endoperoxide synthase 2 (PTGS2) and prostaglandins F2alpha and E2 synthases (PGFS and PGES) expression and prostaglandin F2alpha and E2 secretion following oestrogen and/ or progesterone stimulation of the feline endometrium. Reproduction in Domestic Animals 48 72-78.

Siemieniuch MJ, Jursza E, Szostek AZ, Zschockelt L, Boos A \& Kowalewski MP 2014 Placental origin of prostaglandin F2alpha in the domestic cat. Mediators of Inflammation 2014364787. 
Smith WL \& Dewitt DL 1996 Prostaglandin endoperoxide H synthases-1 and -2. Advances in Immunology 62 167-215. (doi:10.1016/S00652776(08)60430-7)

Stocco CO, Zhong L, Sugimoto Y, Ichikawa A, Lau LF \& Gibori G 2000 Prostaglandin F2alpha-induced expression of 20alpha-hydroxysteroid dehydrogenase involves the transcription factor NUR77. Journal of Biological Chemistry 275 37202-37211. (doi:10.1074/jbc. M006016200)

Sugimoto $Y$, Hasumoto K, Namba T, Irie A, Katsuyama M, Negishi M, Kakizuka A, Narumiya S \& Ichikawa A 1994 Cloning and expression of a cDNA for mouse prostaglandin F receptor. Journal of Biological Chemistry 269 1356-1360.

Tai HH, Ensor CM, Tong M, Zhou H \& Yan F 2002 Prostaglandin catabolizing enzymes. Prostaglandins \& Other Lipid Mediators 68-69 483-493.

Tsai SJ \& Wiltbank MC 1997 Prostaglandin F2alpha induces expression of prostaglandin G/H synthase-2 in the ovine corpus luteum: a potential positive feedback loop during luteolysis. Biology of Reproduction $\mathbf{5 7}$ 1016-1022. (doi:10.1095/biolreprod57.5.1016)

Tsutsui T \& Stabenfeldt GH 1993 Biology of ovarian cycles, pregnancy and pseudopregnancy in the domestic cat. Journal of Reproduction and Fertility. Supplement 47 29-35.

Vandesompele J, De Preter K, Pattyn F, Poppe B, Van Roy N, De Paepe A \& Speleman F 2002 Accurate normalization of real-time quantitative RT-PCR data by geometric averaging of multiple internal control genes. Genome Biology 3 RESEARCH0034.

Vargas A, Sanchez I, Martinez F, Rivas A, Godoy JA \& Roldan E 2008 The Iberian lynx Lynx pardinus Conservation Breeding Program. International Zoo Yearbook 42 190-198. (doi:10.1111/j.17481090.2007.00036.x)

Verhage HG, Beamer NB \& Brenner RM 1976 Plasma levels of estradiol and progesterone in the cat during polyestrus, pregnancy and pseudopregnancy. Biology of Reproduction 14 579-585. (doi:10.1095/ biolreprod 14.5.579)

Vijayakumar R \& Walters WA 1983 Human luteal tissue prostaglandins, 17 beta-estradiol, and progesterone in relation to the growth and senescence of the corpus luteum. Fertility and Sterility 39 298-303.

Weems YS, Bridges PJ, Tanaka Y, Sasser RG, LeaMaster BR, Vincent DL \& Weems CW 1997 PGE1 or PGE2 not LH regulates secretion of progesterone in vitro by the 88-90 day ovine corpus luteum of pregnancy. Prostaglandins 53 337-353.
Wildt DE, Panko WB \& Seager SW 1979 Effect of prostaglandin F2 alpha on endocrine-ovarian function in the domestic cat. Prostaglandins $\mathbf{1 8}$ 883-892. (doi:10.1016/0090-6980(79)90125-4)

Wildt DE, Chan SY, Seager SW \& Chakraborty PK 1981 Ovarian activity, circulating hormones, and sexual behavior in the cat. I. Relationships during the coitus-induced luteal phase and the estrous period without mating. Biology of Reproduction 25 15-28.

Wiltbank MC \& Ottobre JS 2003 Regulation of intraluteal production of prostaglandins. Reproductive Biology and Endocrinology 191. (doi:10.1186/1477-7827-1-91)

Woshner VM, Miller DL, Waldhalm SJ, Cox NM, Jacobson HA \& Leopold BD 2001 Progesterone in luteal bodies of bobcats. Proceedings of the Annual Conference of Southeastern Association of Fish and Wildlife Agencies 55 427-435.

Zambelli D \& Prati F 2006 Ultrasonography for pregnancy diagnosis and evaluation in queens. Theriogenology 66 135-144. (doi:10.1016/j. theriogenology.2006.04.004)

Zhao S \& Fernald RD 2005 Comprehensive algorithm for quantitative realtime polymerase chain reaction. Journal of Computational Biology 12 1047-1064. (doi:10.1089/cmb.2005.12.1047)

Zschockelt L, Amelkina O, Siemieniuch MJ, Koster S, Jewgenow K \& Braun BC 2014 Corpora lutea of pregnant and pseudopregnant domestic cats reveal similar steroidogenic capacities during the luteal life span. Journal of Steroid Biochemistry and Molecular Biology 144 373-381. (doi:10.1016/j.jsbmb.2014.08.010)

Zschockelt L, Amelkina O, Koster S, Painer J, Okuyama MW, Serra R, Vargas A, Jewgenow K \& Braun BC 2015 Comparative analysis of intraluteal steroidogenic enzymes emphasises the functionality of fresh and persistent corpora lutea during pro-and metoestrus in the lynx. Journal of Steroid Biochemistry and Molecular Biology 154 75-84. (doi:10.1016/j.jsbmb.2015.07.001)

Received 4 April 2016

First decision 26 April 2016

Revised manuscript received 18 May 2016

Accepted 23 May 2016 